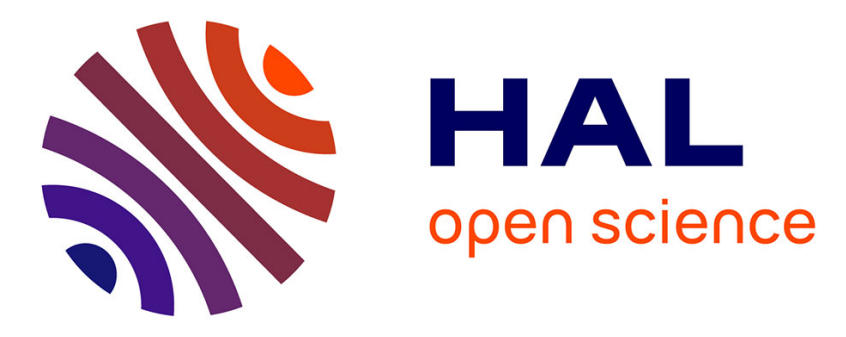

\title{
Dye Anchoring on CuCrO2 Surfaces for p-Type Dye-Sensitized Solar Cell Applications: An Ab Initio Study
}

Dimple Dimple, Sébastien Lebègue, Mariachiara Pastore

\section{- To cite this version:}

Dimple Dimple, Sébastien Lebègue, Mariachiara Pastore. Dye Anchoring on CuCrO2 Surfaces for p-Type Dye-Sensitized Solar Cell Applications: An Ab Initio Study. ACS Applied Energy Materials, 2021, 4 (6), pp.6180-6190. 10.1021/acsaem.1c00970 . hal-03421115

\section{HAL Id: hal-03421115 \\ https://hal.science/hal-03421115}

Submitted on 9 Nov 2021

HAL is a multi-disciplinary open access archive for the deposit and dissemination of scientific research documents, whether they are published or not. The documents may come from teaching and research institutions in France or abroad, or from public or private research centers.
L'archive ouverte pluridisciplinaire HAL, est destinée au dépôt et à la diffusion de documents scientifiques de niveau recherche, publiés ou non, émanant des établissements d'enseignement et de recherche français ou étrangers, des laboratoires publics ou privés.

\section{(c)(1)}

Distributed under a Creative Commons Attribution| 4.0 International License 


\title{
Dye anchoring on $\mathrm{CuCrO}_{2}$ surfaces for p-type DSSCs applications: an ab initio study
}

\author{
Dimple Dimple $^{a}$, Sébastien Lebègue ${ }^{a}$ and Mariachiara Pastore ${ }^{a, *}$
}

${ }^{a}$ Université de Lorraine \& CNRS,

LPCT, UMR 7019, F-54000 Nancy, France

May 11, 2021

*corresponding author: mariachiara.pastore@univ-lorraine.fr 


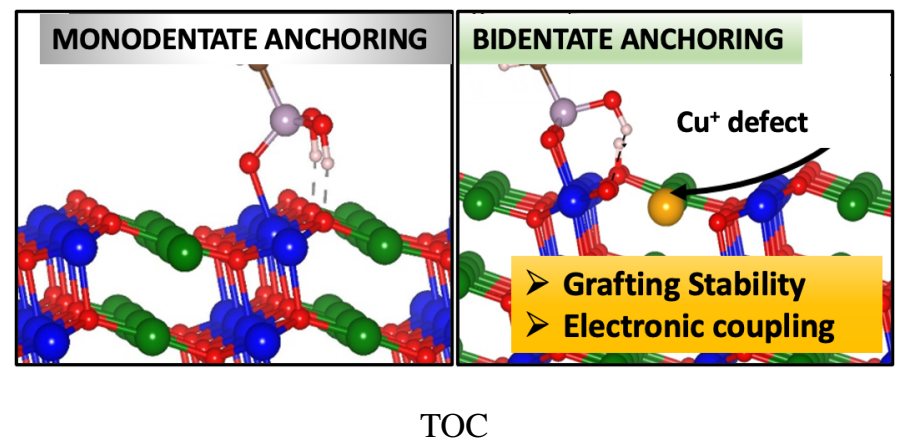




\begin{abstract}
The possibility of stably anchoring dye molecules on the exposed surface of a p-type semiconductor is crucial to have efficient dye-sensitized photoelectrodes. Here, we theoretically characterize the adsorption mechanism of carboxylic and phosphonic anchoring groups onto the (012) surface of stoichiometric and reduced $\mathrm{CuCrO}_{2}$ delafossite. Density Functional Theory is employed to accurately predict the preferred adsorption modes and their energies, both in gas phase and solution (water and acetonitrile). On the stoichiometric (012) surface, we found a strong selectivity toward the molecular monodentate binding modes at the highly active Cr-sites, stabilized by strong Hydrogen-bonds with the surface oxygens, for both anchoring groups; deprotonated bidentate bridging anchoring is only identified when the proton transferred to the surface is kept far away from the molecule during the structural relaxation process. On the other hand, the bidentate anchoring becomes the preferred adsorption mode when $\mathrm{Cu}^{+}$vacancies are considered at the topmost layer of the surface slab. The identification of stable bidentate bridging anchoring modes on the $\mathrm{CuCrO}_{2}$ surface might have important implications for the device stability, as well as for the efficiency of the interfacial hole injection and suggest it as an alternative material to $\mathrm{NiO}$ for p-type DSSCs.
\end{abstract}

keywords: DSSCs; p-type semiconductors; $\mathrm{Cu}(\mathrm{I})$ delafossite; $\mathrm{CuCrO}_{2}$; dye anchoring; $\mathrm{Cu}$ vacancies; DFT modeling

\title{
1 Introduction
}

Dye-sensitized solar cells (DSSCs) hold great promise as efficient photovoltaic devices, alternative to traditional Silicon-based technologies. ${ }^{1}$ Thus, since their first inception in 1991 by O’Regan and Grätzel, ${ }^{2}$ considerable research efforts have been addressed to the development of high-performing, low-cost and durable DSSCs. So far, the highest DSSCs power conversion efficiency is $\sim 14 \%$ using an n-type $\mathrm{TiO}_{2}$ photoanode as the working electrode. ${ }^{3}$ Alternatively, one can build a p-type DSSC, working in a reverse way, where the photoactive electrode is a dye-sensitized mesoporous transparent p-type semiconductor. The first example of a p-type DSSC was reported, indeed, in 1999 by Lindquist and co-workers using a porphyrin dye as a photosensitizer, nanoporous $\mathrm{NiO}$ as a p-type semiconductor to load the dye, and a liquid $\mathrm{I}^{-} / \mathrm{I}_{3}^{-}$ electrolyte redox mediator to undertake electron transport between the counter electrode and the photocathode. ${ }^{4}$ Subsequently, p-type DSSCs have been gaining tremendous interest due to their potential applications in the preparation of tandem dye-sensitized solar cells in cooperation with conventional n-type DSSCs. ${ }^{5,6}$ Despite the extensive research efforts to develop efficient 
p-type electrodes, however, their solar-energy-to-electric-energy conversion efficiency is still one order of magnitude smaller that the n-type DSSCs, with the reported record efficiency of $2.5 \%$ for a NiO-based solar cell. ${ }^{7}$

The under performance of NiO-based DSSCs with respect to n-type counterparts is ascribed to a multitude of factors: (1) the $\mathrm{I}^{-} / \mathrm{I}_{3}^{-}$redox couple, commonly used in DSSCs, yields low photovoltages due to the small energy difference with the valence band (VB) offset of $\mathrm{NiO} ;(2)$ the low hole mobility of $\mathrm{NiO}$, with a diffusion coefficient of $10^{-8}-10^{-7} \mathrm{~cm}^{2} \mathrm{~s}^{-1},{ }^{8}$ being more than two orders of magnitude lower than the electron diffusion coefficient of $\mathrm{TiO}_{2}$, may favor fast back recombination process; (3) the quite low dielectric constant of $\mathrm{NiO}(\varepsilon=9.7)$, compared to that of $\mathrm{TiO}_{2}(\varepsilon=80)$, can cause the injected hole to be strongly bound with the electron residing on the dye, thus limiting the charge generation as suggested for $\mathrm{ZnO}(\varepsilon=8)$ based $\mathrm{n}$ type DSSCs. ${ }^{9}$ Such drawbacks in the use of $\mathrm{NiO}$ as sensitized photocathode are pushing toward the development of alternative p-type photocathodic materials, like, for instance, copper $(\mathrm{Cu})$ based delafossite oxides, ${ }^{10}$ oxysulfides ${ }^{11,12}$ and spinels materials. ${ }^{13}$

In particular, in the recent years, p-type $\mathrm{Cu}$ delafossite oxides have been hogging the limelight owing to their superior optoelectronic properties when compared to $\mathrm{NiO} .{ }^{10,14-20}$ The general formula of these delafossite oxides is $\mathrm{Cu}^{+} \mathrm{M}^{3+} \mathrm{O}_{2}$, where $\mathrm{M}^{3+}=\mathrm{B}^{3+}, \mathrm{Al}^{3+}, \mathrm{Ga}^{3+}, \mathrm{In}^{3+}$, $\mathrm{Cr}^{3+}$, etc). In such delafossites, the mixing of $\mathrm{Cu}-3 \mathrm{~d}$ states and $\mathrm{O}-2 \mathrm{p}$ states forming the $\mathrm{VB}$ leads to a higher hole mobility. Tailoring the edge of the VB by mixing molecular orbitals of the cations was proposed as a valuable strategy by Hosono and co-workers and demonstrated for $\mathrm{CuAlO}_{2}$ as the first p-type transparent delafossite. ${ }^{21}$ In the quest for higher-performing $\mathrm{p}$ type delafossite oxides, $\mathrm{CuCrO}_{2}$ has been the focus of recent interest due to its high density of states of $3 \mathrm{~d}$ chromium orbitals near the maximum of the VB and the covalent mixing between chromium and oxygen ions. ${ }^{22,23}$ These two properties promote a larger hole mobility and hence a greater conductivity is expected in this material. In 2012, Chen's group ${ }^{16}$ reported the hydrothermal synthesis of small $\mathrm{CuCrO}_{2}$ nanocrystals and applied them as photocathodes in p-type DSSCs. The deeper VB edge position of $\mathrm{CuCrO}_{2}(+0.84 \mathrm{~V}$ vs. Normal Hydrogen Electrode (NHE)) compared to $\mathrm{NiO}(+0.56 \mathrm{~V}$ vs. NHE) was confirmed using a Mott-Schottky analysis. ${ }^{16}$ In recent studies, Ahmadi et al. ${ }^{24}$ reported a record value $\left(280 \mathrm{~S} . \mathrm{cm}^{-1}\right)$ for the elec- 
tric conductivity in $\mathrm{CuCrO}_{2}$ co-doped with $\mathrm{Mg}$ and $\mathrm{N}$. Resiner and coworkers had shown that $\mathrm{CuCrO}_{2}$ photocathodes outperforms $\mathrm{NiO}$ yielding a higher onset potential of $+0.75 \mathrm{~V}$ and an increased photocurrent $\left(15 \mu \mathrm{A} . \mathrm{cm}^{-2}\right){ }^{25}$ Also, Powar et. al ${ }^{14}$ observed a high transient lifetime between the photo-generated dye anion and the electron vacancy (hole) in $\mathrm{CuCrO}_{2}(140 \pm 15$ $\mu \mathrm{s})$ compared to $\mathrm{NiO}$ DSSCs $(24 \pm 0.4 \mu \mathrm{s})$, which indicates an overall reduced recombination rate for $\mathrm{CuCrO}_{2}$.

Despite the optimal opto-electronic properties of $\mathrm{Cu}$-delafossites, their use in DSSCs did not result yet in an overall significant increase of photocurrent and device's efficiency. ${ }^{10,26}$ To this end, boosting the performance of photocathodes requires acquiring fundamental knowledge on the structure, energetics and charge generation properties of the dye/oxide interface. Apart from the individual optoelectronic properties of dyes and semiconductors, a salient feature of efficient photoelectrodes is the formation of strong and stable dye-surface linkages, realized through the use of anchoring groups on the dye, which should also assure an efficient electronic coupling between the molecule and the metal oxide. ${ }^{27}$ Historically, the two commonly employed anchoring groups in DSSCs are: carboxylic acid $(-\mathrm{COOH})$ and phosphonic acid $\left(-\mathrm{PO}_{3} \mathrm{H}_{2}\right)$. Different adsorption modes are likely to exist, with possibly different implications for the interfacial charge separation and the long-term stability. ${ }^{27}$ Along with experimental investigations, a number of theoretical works have focused on the dye adsorption modes on the anatase $\mathrm{TiO}_{2}$ surface. ${ }^{28,31}$ In the case of carboxylic anchoring, most of the calculations pointed to the bidentate bridging mode with proton transfer to the surface as the most stable one, while monodentate anchoring was usually found to be less stable; it is worthwhile to note, however, a certain dependency of the relative stability of these two adsorption modes on the employed level of theory. As far as phosphonic acid is concerned, while there is no clear experimental assignment of the most stable adsorption mechanism, theoretical works identified either monodentate or bidentate bridging modes as the preferred ones. ${ }^{29}$ Typical calculated adsorption energies in vacuo for $-\mathrm{COOH}$ and $-\mathrm{PO}_{3} \mathrm{H}_{2}$ onto the most stable (101) $\mathrm{TiO}_{2}$ anatase surface are of ca. 1.2 and $1.8 \mathrm{eV}$, respectively, ${ }^{30}$ with the latter giving stronger binding (higher device stability) at the price of a reduced electronic coupling (lower photocurrents). To date, on the other hand, a limited number of theoretical studies have been conducted to investigate the ad- 
sorption mechanism of anchoring groups or dyes on p-type semiconducting surfaces. ${ }^{32-34,36,37}$ While there is an overall agreement on the identification of the bidentate bridging mode as the preferred one for both carboxylic and phosphonic groups anchoring to the (100) $\mathrm{NiO}$ surface at $0 \mathrm{~K}$, the calculated binding energies reported in the literature strongly variate depending on the slab models and level of theory employed, with values ranging from about 0.8 to more than $3 \mathrm{eV} .{ }^{32-34}$ Very recently Pavone and co-workers ${ }^{37}$ reported a DFT study on the grafting of carboxylic and phosphonic groups onto pristine and $\mathrm{Mg}$-doped $\mathrm{CuGaO}_{2}$ surfaces, identifying monodentate configurations on the Ga sites as the most stable one, with calculated adsorption energies in vacuo of ca. 0.8 and $1.0 \mathrm{eV}$ for $\mathrm{CH}_{3}-\mathrm{COOH}$ and $\mathrm{CH}_{3}-\mathrm{PO}_{3} \mathrm{H}_{2}$, respectively. Interesting, no stable bidentate or tridentate (for the phosphonic group) adsorption modes were obtained.

To the best of our knowledge, on the other hand, nothing is known, from both a theoretical and experimental point of view, about the adsorption of carboxylic and phosphonic acids on $\mathrm{CuCrO}_{2}$ surfaces, despite its promising performances in DSSCs. Here we tackle this issue, reporting a systematic Density Functional Theory (DFT) investigation of the adsorption mechanism of $\mathrm{CH}_{3}-\mathrm{COOH}$ and $\mathrm{CH}_{3}-\mathrm{PO}_{3} \mathrm{H}_{2}$ on the high-index (012) $\mathrm{CuCrO}_{2}$ surface, considering implicit solvation effects and also taking into account the impact of $\mathrm{Cu}^{+}$vacancies on the different adsorption modes as well as on their stability. In earlier studies, $\mathrm{Cu}$ vacancies have been discussed mainly to understand the p-type conductivity of delafossites. ${ }^{22,38-40}$ Herein, we present $\mathrm{Cu}^{+}$vacancy point defect and highlight their importance in stabilizing bidentate bridging (BB) modes.

\section{Computational Methodology}

Spin-polarized periodic density-functional theory (DFT) calculations were performed with the Vienna Ab initio Simulation Package (VASP) code. ${ }^{41,42}$ The exchange correlation potential was described by Perdew-Burke-Ernzerhof ${ }^{43}$ (PBE) functional within the generalized gradient approximation (GGA). The projector augmented wave method was used as the basis set. ${ }^{44,45}$ For bulk $\mathrm{CuCrO}_{2}$, a full optimization of the cell parameters was carried out by using a cutoff energy of $550 \mathrm{eV}$ and a $13 \times 13 \times 2 \Gamma$-centered k-point sampling. Geometric relaxation was 
deemed to be converged when the forces on all the atoms were less than $0.001 \mathrm{eV} / \AA$. To describe the strong-correlated nature of the $\mathrm{Cu}$ and $\mathrm{Cr} 3 \mathrm{~d}$ electrons, we applied the rotationally invariant DFT+U approach of Dudarev ${ }^{46}$ as implemented in VASP. ${ }^{47}$ Based on the previous work of Scanlon et. al, ${ }^{48}$ we choose effective $\mathrm{U}$ values of $5.2 \mathrm{eV}$ for the $\mathrm{Cu}-3 \mathrm{~d}$ states and $4.0 \mathrm{eV}$ for the Cr-3d states.

An orthorhomic supercell with lattice parameters $a=12.06 \AA$ and $b=17.93 \AA$ has been purposefully used for the surface adsorption calculations. The Brillouin zone was sampled with a $3 \times 2 \times 1 \Gamma$-centered k-mesh. A vacuum thickness of more than $16 \AA$ has been used to decouple the periodic images between adjacent surfaces in the thickness direction along c-axis. The DFTD2 van der Waals (vdWs) correction proposed by Grimme ${ }^{49}$ has been adopted to describe the long-range dispersive interactions as implemented in VASP. ${ }^{50}$ Dipole and quadrupole corrections were applied along the direction perpendicular to the surface in order to eliminate spurious electrostatic interactions between periodic images.

In order to compare the adsorption energies, we have employed the PBE, $\mathrm{PBE}+\mathrm{D} 2, \mathrm{PBE}+\mathrm{U}$ and $\mathrm{PBE}+\mathrm{U}+\mathrm{D} 2$ methods in the vacuum. The binding energies were computed as the difference between the total energies of the combined adsorbate/substrate system and the (012) $\mathrm{CuCrO}_{2}$ surface plus an isolated molecule,

$$
\Delta E_{\text {ads }}=E_{\text {adsorbate } / \text { substrate }}-\left(E_{\text {substrate }}+E_{\text {adsorbate }}\right)
$$

For implicit solvation calculations, we used VASPsol, ${ }^{51}$ a package that incorporates solvation calculations into VASP within a self-consistent linear polarizable continuum model (PCM). The solvation energies in implicit water $\left(\varepsilon_{\text {water }}=80.0\right)$ and acetonitrile $\left(\varepsilon_{\text {acetonitrile }}=37.5\right)$, the latter being a commonly employed solvent in DSSCs, were evaluated by performing single-point energy calculations on the structures optimized in vacuo, keeping the defaults setting parameters. $^{52}$ 


\section{Results and Discussion}

This section is organized as follows: first, a brief description of bulk $\mathrm{CuCrO}_{2}$ delafossite and its (012) surface properties will be given. Next, the choice of the supercell used is presented, and finally, the adsorption modes of the $\mathrm{CH}_{3}-\mathrm{COOH}$ and $\mathrm{CH}_{3}-\mathrm{PO}_{3} \mathrm{H}_{2}$ molecules on the (012) $\mathrm{CuCrO}_{2}$ surface slab will be discussed.

\subsection{Bulk $\mathrm{CuCrO}_{2}$ and its (012) surface}

Bulk $\mathrm{CuCrO}_{2}$ exists in two polytypes, namely: a rhombohedral 3R and a hexagonal $\mathrm{H}$-type, depending on the stacking of in-plane copper $\left(\mathrm{Cu}^{+}\right)$atoms and its edge-shared (regular) octahedron by chromium oxide $\left(\mathrm{CrO}_{6}\right)$ layers with $\mathrm{d}_{C r-O}=2.03 \AA$ along the z-direction. These planes are connected by dumbbell-like $\mathrm{O}-\mathrm{Cu}-\mathrm{O}\left(\mathrm{d}_{C u-O}=1.85 \AA\right)$ bridges. Experimentally, $\mathrm{CuCrO}_{2}$ crystallizes at room temperature in the $3 \mathrm{R}$ polytype with the $\mathrm{R} \overline{3} \mathrm{~m}$ space group symmetry. ${ }^{53} \mathrm{We}$ modeled the crystal structure of $3 \mathrm{R} \mathrm{CuCrO}_{2}$ in an hexagonal setting as shown in Figure 1 (a). The calculated lattice constants and structural parameters using the PBE and PBE+U levels of theory are tabulated in Table 1. These parameters are in good agreement with those reported in other theoretical and experimental studies. ${ }^{53,54}$ Moreover, bulk $\mathrm{CuCrO}_{2}$ is reported as a triangular lattice antiferromagnetic (AFM) $)^{55}$ insulator with a band gap $>3 \mathrm{eV}^{56}$ and a magnetic moment of $3.0 \mu_{B}$. Although we found similar kind of anti-ferromagnetism in the ground state, the calculated difference between the anti-ferromagnetic and ferromagnetic ground state energy was about $0.1 \mathrm{eV}$, consistently with previous results. ${ }^{57}$ Therefore, in the present work, we have purposefully chosen the ferromagnetic state due to its smaller unit-cell requirement and simplicity (Figure 1 (a)).

Our simulated PXRD (powder x-ray diffraction) along with the experimental reference data $^{16,58}$ shows that different possible facets exist (such as (006), (012), (104), (110) etc.) for bulk $\mathrm{CuCrO}_{2}$, although the preferred orientation is along its (012) high index plane as shown in Figure 1 (b). 
Table 1: Optimized PBE and PBE+U structural parameters of bulk $3 \mathrm{R}-\mathrm{CuCrO}_{2}$ : lattice constants (a and c in $\AA$ ), volume, $\mathrm{V}$ (in $\AA^{3}$ ), bond lengths, $\mathrm{d}$ (in $\AA$ ) and magnetic moment, $\mu$ (in $\mu_{B}$ ); results of earlier experimental and theoretical studies are also reported for the sake of comparison.

\begin{tabular}{|c|c|c|c|c|c|c|}
\hline & $\mathrm{a}(\AA)$ & $\mathrm{c}(\AA)$ & $\mathrm{V}\left(\AA^{3}\right)$ & $\mathrm{d}_{C u-O}(\AA)$ & $\mathrm{d}_{C r-O}(\AA)$ & $\mu\left(\mu_{B}\right)$ \\
\hline \hline PBE & 3.02 & 17.15 & 135.24 & 1.86 & 2.01 & 3.00 \\
\hline PBE+U & 3.06 & 17.15 & 138.72 & 1.85 & 2.03 & 3.00 \\
\hline Exp. & $2.98^{a, b}, 2.97^{c}$ & $17.11^{a, b}, 17.06^{c}$ & $131.2^{a}$ & - & - & - \\
\hline Th. & $2.99^{d}, 3.03^{e}$ & $17.31^{d}, 17.17^{e}$ & - & - & - & - \\
\hline \multicolumn{7}{|c|}{ Ref. $\mathrm{a}^{54} \mathrm{~b}^{53}{ }^{53},{ }^{59} \mathrm{~d}^{60}$ and $\mathrm{e}^{61}$}
\end{tabular}
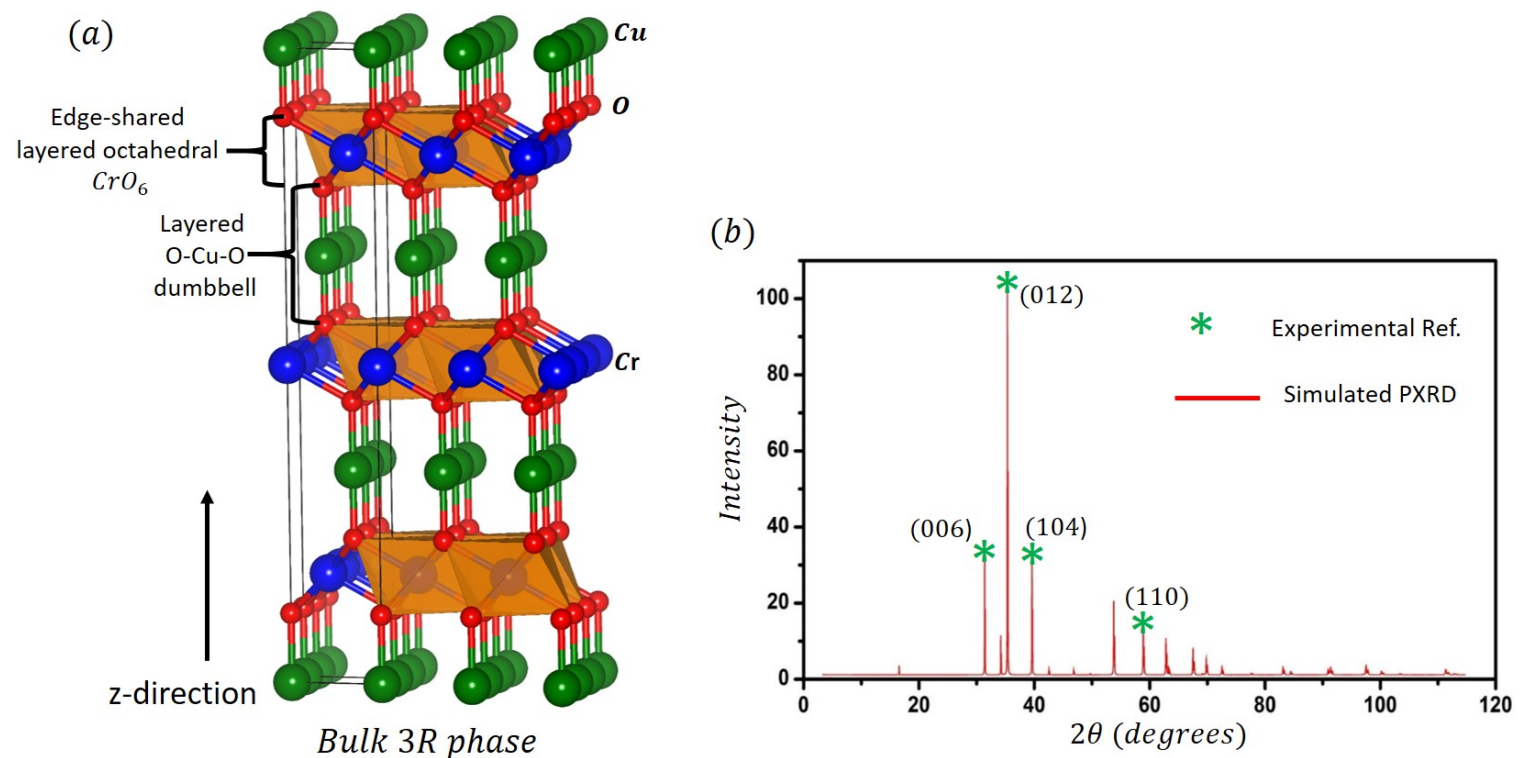

Figure 1: (a) Bulk $\mathrm{CuCrO}_{2}$ delafossite (3R) crystal structure where copper atoms (green) lie in-plane and stack alternatively with edge-shared chromium oxide layers in the z-direction. (b) The simulated PXRD plot along with experimental reference shows the different possible facets of $\mathrm{CuCrO}_{2}$.

Thus, we cleaved the (012) surface by taking into consideration its symmetry and stoichiometry in a periodic orthorhombic supercell as shown in Figure 2. We considered a surface slab composed of five layers $(60 \mathrm{Cr}, 60 \mathrm{Cu}$ and $120 \mathrm{O}$ atoms), in which the ferromagnetic ordering of bulk $\mathrm{CuCrO}_{2}$ is preserved. To avoid spurious interaction between periodic replica, a vacuum space of $\simeq 16 \AA$ along the direction perpendicular to the surface was considered in the 
simulations. The calculated surface energy for this symmetric and stochiometric $\mathrm{CuCrO}_{2} \mathrm{slab}$, obtained as the difference between the energy of the slab and that of bulk divided by twice the surface area of the slab, ${ }^{18}$ is $0.914 \mathrm{~J}_{\mathrm{m}} \mathrm{m}^{-2}$ and $0.962 \mathrm{~J} . \mathrm{m}^{-2}$ at the PBE and PBE+U levels of theory, respectively.

The surface morphology of the (012) $\mathrm{CuCrO}_{2}$ surface is akin to a corrugated (non-planar) surface and is a mixture of all the cations $\left(\mathrm{Cu}^{+}\right.$and $\left.\mathrm{Cr}^{3+}\right)$ and anions $\left(\mathrm{O}^{2-}\right)$ species available in the bulk component of $\mathrm{CuCrO}_{2}$ as shown in Figure 2. The surface and sub-surface $\mathrm{Cu}^{+}$ atoms present the same bond coordination with the oxygen atoms, thus explaining their low reactivity to coordinate the molecule, as we shall discuss later. On the other hand, the surface $\mathrm{Cr}^{3+}$ and oxygen species are different from their respective sub-surface layers. The sub-surface $\mathrm{Cr}^{3+}$ atoms linked with six nearest neighboring oxygen atoms form a $\mathrm{CrO}_{6}$ regular octahedral geometry, whereas on the surface, it is coordinated with just three oxygen atoms and exists in a distorted semi-octahedral form with $\mathrm{d}_{C r-O_{B}}=2.03 \AA$ and $\mathrm{d}_{C r-O_{A}}=1.93 \AA$, where the surface oxygen atoms are of two types $\left(\mathrm{O}_{A}\right.$ and $\left.\mathrm{O}_{B}\right)$ on the $(012)$ surface. Half the fraction of oxygen atoms, $\mathrm{O}_{B}$, form the usual linkage as available for the sub-surface oxygen atoms i.e. each oxygen atom is linked with their nearest neighbors of three $\mathrm{Cr}$ and one $\mathrm{Cu}$ atoms (see Figure 2); the other half fraction, $\mathrm{O}_{A}$, form bonds with two $\mathrm{Cr}$ and one $\mathrm{Cu}$ atom. 


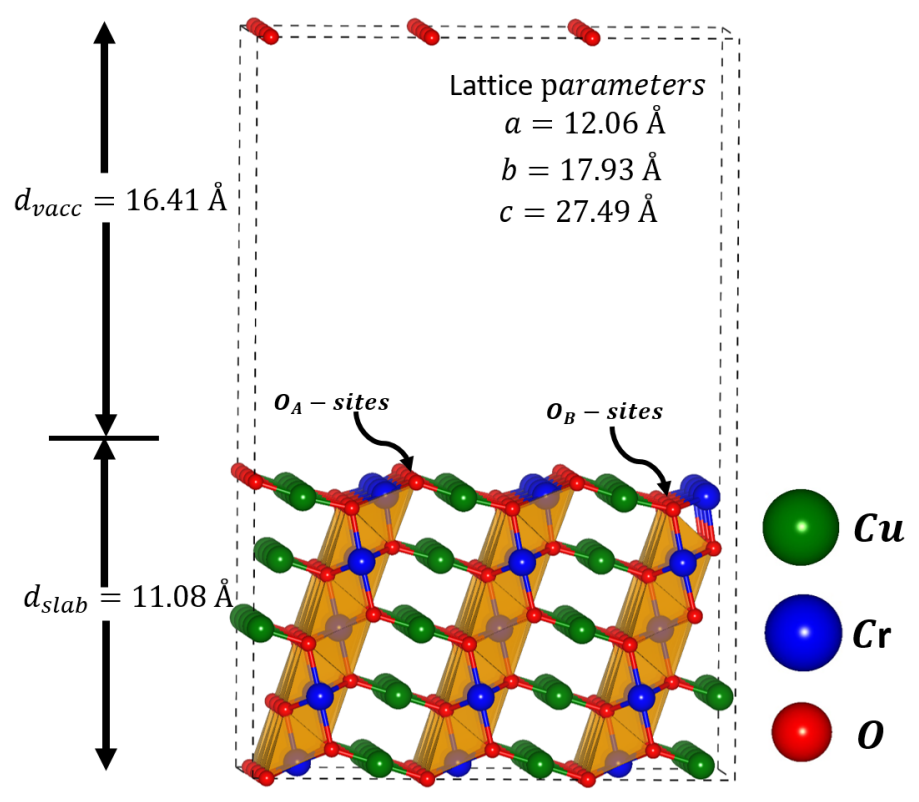

Figure 2: The (012) surface in a periodic orthorhombic supercell with its cell parameters after cleaving bulk $\mathrm{CuCrO}_{2}$. A distorted semi-octahedral of $\mathrm{CrO}_{6}$ formed with cleavage which is different from sub-layer regular octahedral. The surface $\mathrm{O}_{A}$-site and $\mathrm{O}_{B}$-site represent the two different types of surface oxygen atoms. $\mathrm{O}_{A}$ are the surface oxygen atoms that form the active sites as they are linked with two $\mathrm{Cr}$ and one $\mathrm{Cu}$ atom. $\mathrm{O}_{B}$ are surface oxygen atoms that form the usual bond linkage as available for the sub-surface oxygen atoms i.e. each oxygen atom linked with their nearest neighbors of three $\mathrm{Cr}$ and one $\mathrm{Cu}$ atom.

\subsection{Acetic acid on (012) $\mathrm{CuCrO}_{2}$}

The $-\mathrm{COOH}$ anchoring group is probably the most widely employed in DSSCs, since it assures high electronic coupling between the dye and the semiconductor, essential to allow fast interfacial hole/electron transfers. When interacting with a semiconductor substrate, the acidic proton can be either transferred to the oxide surface (both in a bidendate and monodentate anchoring mode) or be retained on the molecule and possibly interact with a surface oxygen via hydrogen-bonding. ${ }^{27,62}$ If we consider the (012) $\mathrm{CuCrO}_{2}$ surface, as schematized in Figure 3, in principle, two monodentate modes can exist, depending on whether the covalent bond is established with the $\mathrm{Cu}\left(\mathrm{M}-\mathrm{Cu}_{H}\right)$ or $\mathrm{Cr}\left(\mathrm{M}-\mathrm{Cr}_{H}\right)$ atom. The sub-index "H"indicate that $-\mathrm{OH}$ group can form $\mathrm{H}$-bonding with an oxygen surface atom. Upon deprotonation and proton transfer to the surface, three possible bidentate bridging modes can occur: $\mathrm{BB}-\mathrm{Cu}-\mathrm{Cu}, \mathrm{BB}-\mathrm{Cr}-\mathrm{Cr}$ and 
$\mathrm{BB}-\mathrm{Cu}-\mathrm{Cr}$, depending on the metal atoms to which the carboxylate anion is linked to.

Starting from the five guess adsorption configurations displayed in Figure 3, after structure relaxation, we ended up with only three stable adsorption modes, as shown in Figure 4: two monodentate coordinations on the $\mathrm{Cr}$ atom, $\mathrm{M}-\mathrm{Cr}_{H}$, where the proton is shared by the molecule and by a nearby surface oxygen atom, and M-Cr, resulted from the optimization of the bidentate $\mathrm{BB}-\mathrm{Cu}-\mathrm{Cr}$ mode, and one bidentate bridging anchoring, $\mathrm{BB}-\mathrm{Cr}-\mathrm{Cr}$. In other terms, covalent coordination to $\mathrm{Cu}$ atoms is unstable, as it could be expected on the basis of the fact that the surface $\mathrm{Cu}$ atoms are fully coordinated, presenting the same coordination of the bulk ones. Upon relaxation, indeed, the $\mathrm{M}-\mathrm{Cu}_{H}$ and the $\mathrm{BB}-\mathrm{Cu}-\mathrm{Cu}$ modes were converted into the $\mathrm{M}-\mathrm{Cr}_{H}$ and $\mathrm{BB}-\mathrm{Cr}-\mathrm{Cr}$ ones, respectively and the $\mathrm{O}-\mathrm{Cu}$ bond in the $\mathrm{BB}-\mathrm{Cu}-\mathrm{Cr}$ was broken yielding the deprotonated monodentate $\mathrm{M}-\mathrm{Cr}$ configuration. It is important to stress here that, following the approach employed in Ref., ${ }^{37}$ in building the initial guess structures of the BB modes, to avoid the transferred proton to go back to the molecule as in the case, for example, of the deprotonated monodentate $\mathrm{M}-\mathrm{Cr}$, we placed the $\mathrm{H}^{+}$sufficiently far from the anchoring group. This allowed us to identify all possible grafting modes, less stable at neutral or acidic $\mathrm{pH}$, that might be present, however, when organic bases are added to the electrolyte. ${ }^{63,64}$ The corresponding selected structural parameters of the optimized $\mathrm{CH}_{3}-\mathrm{COOH} @ \mathrm{CuCrO}_{2}$ modes, together with their binding energies, obtained at the PBE+U+D2 level of theory, are listed in Table 2 and Table 3, respectively.

As indicated by the optimized structural parameters in Table 2, the $\mathrm{O}-\mathrm{Cr}$ bond distances are rather short, around $2 \AA$, with the shortest value of $1.97 \AA$ exhibited by the M-Cr structure. Similar values were reported in Ref. ${ }^{37}$ for the $\mathrm{CuGaO}_{2}$ surface. In the case of the $\mathrm{M}-\mathrm{Cr}_{H}$ configuration, interestingly, the proton is almost uniformly shared by the carboxylic and the surface oxygen atoms, with bond distances of $1.37 \AA$ and $1.10 \AA$. This explains the relatively high stabilization of this monodentate adsoprtion on the $\mathrm{CuCrO}_{2}$ surface, with a binding energy being more than two-fold in magnitude with respect to that of the monodentate and bidentate adsorption modes of acetic acid on $\mathrm{NiO}(001)$ and on the $(012) \mathrm{CuGaO}_{2}$ surface. ${ }^{37}$ As is apparent by comparing the dispersion-corrected binding energies in Table 3 with the ones reported in Table S1 in Supporting Information, inclusion of Grimme's correction has a major role in 

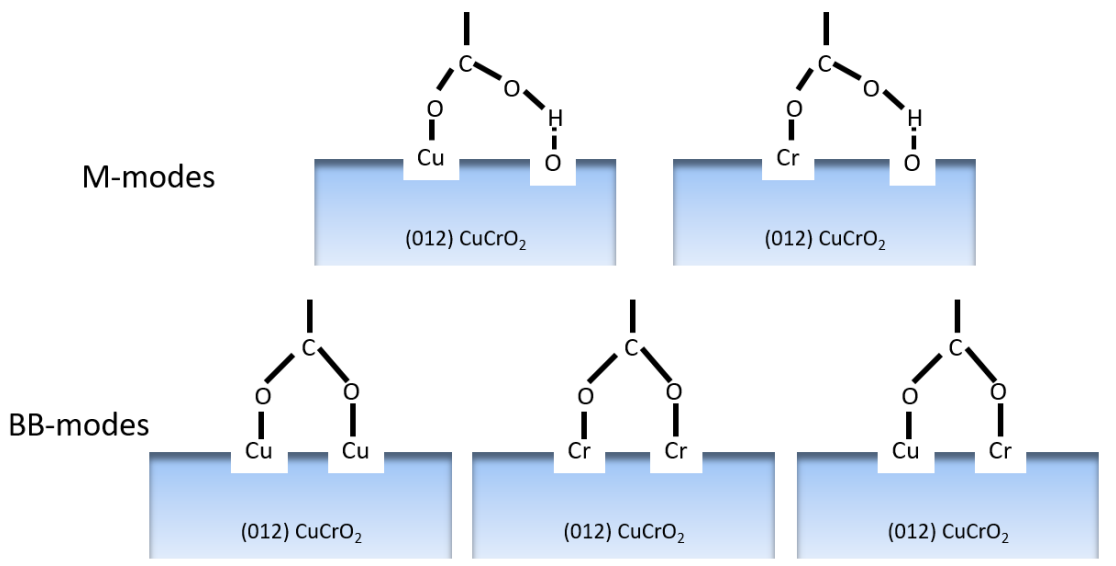

Figure 3: Schematic representation of all possible binding modes for a carboxylic acid $(-\mathrm{COOH})$ anchoring on $\mathrm{CuCrO}_{2}(012)$ surface: monodentate $(\mathrm{M})$ modes $\left(\mathrm{M}-\mathrm{Cu}_{H}\right.$ and $\mathrm{M}$ $\mathrm{Cr}_{H}$ ), bidentate bridging (BB) modes (BB-Cu-Cu, BB-Cr-Cr and $\mathrm{BB}-\mathrm{Cu}-\mathrm{Cr}$ ). The sub index "H"indicates $\mathrm{H}$-bonding (dashed line) between the $\mathrm{OH}$ group and a surface oxygen atom.

stabilizing the molecule anchoring on the surface, and our best estimates of the adsorption energies $(\mathrm{PBE}+\mathrm{U}+\mathrm{D} 2)$ indicate the monodentate $\mathrm{M}-\mathrm{Cr}_{H}$ as the preferred adsorption mode in gas phase, with an adsorption energy of $0.3 \mathrm{eV}$ higher than the bidentate $\mathrm{BB}-\mathrm{Cr}-\mathrm{Cr}$ mode $(-1.66$ vs. $-1.36 \mathrm{eV}$, in Table 3). Differently to what reported in Ref. 37, where no stable bidentate adsorption was found, we predict the anchoring on two $\mathrm{Cr}$ atoms, $\mathrm{BB}-\mathrm{Cr}-\mathrm{Cr}$, to have quite a large binding energy in gas phase and to be further stabilized with respect to the monodentate configurations when implicit solvation is accounted for. Both in acetonitrile and water solution, indeed, the stability of the molecular monodentate adsorption mode slightly reduces due to the dielectric screening of the strong $\mathrm{H}$-bond with the surface and the $\mathrm{M}-\mathrm{Cr}_{H}$ and $\mathrm{BB}-\mathrm{Cr}-\mathrm{Cr}$ configurations become isoenergetics. Inclusions of the solvent, clearly also stabilizes the dissociated monodentate mode, $\mathrm{M}-\mathrm{Cr}$, presenting a dangling $\mathrm{C}-\mathrm{O}$ bond.

Under growth conditions of delafossites, the dominant intrinsic p-type defects are the $\mathrm{Cu}^{+}$vacancies. ${ }^{40,65}$ Therefore, in order to refine our structural model of the $\mathrm{CuCrO}_{2}(012)$ surface and investigate the effect of native $\mathrm{Cu}$ vacancies on the $-\mathrm{COOH}$ adsorption mechanism and energetics, we created single $\mathrm{Cu}$ defects on the two uppermost surface layers, in proximity of the adsorbed molecule; we will hereafter refer to this surface as "reduced surface". The presence of a single $\mathrm{Cu}^{+}$vacancy on our slab gives a defect percentage of $1.7 \%$, which is reasonable con- 
sidering the experimental value ( $4 \pm 2 \%$ ) obtained for $\mathrm{CuGaO}_{2}$ via XPS (X-ray Photoelectron Spectroscopic) measurements. ${ }^{40}$ A comparison between the total and partial density of states of the pristine and reduced surfaces shows that the $\mathrm{Cu}$ vacancy does not introduce significant intra-gap states (see Figure S3 in Supporting Information). Moreover, by looking at the difference in the Bader's charges between the clean and defective slabs (Figure S4 in Supporting Information), one can notice that the charges on the $\mathrm{Cr}$ atoms are only marginally changed by the presence of the defect, with a difference of charge of 0.04 electrons. The different positions of the $\mathrm{Cu}^{+}$vacancy considered here are displayed in Figure 5, and the corresponding binding energies listed in Table 3. We examined both monodentate $\left(\mathrm{M}_{-} \mathrm{Cr}_{H}\right)$ and bidentate-bridging (BB-Cr-Cr) adsorption configurations, creating a defect on the left $\left(\mathrm{V}_{1}^{L}\right.$ and $\mathrm{V}_{2}^{L}$ on the first and second layer, respectively) and right sides $\left(\mathrm{V}_{1}^{R}\right.$ and $\mathrm{V}_{2}^{R}$ on the first and second layer, respectively). When considering the four defects in the case of the $\mathrm{M}-\mathrm{Cr}_{H}$ mode, the first interesting finding is the possible stabilization of a bidentate anchoring form $\left(\mathrm{V}_{1 H}^{R} \mathrm{BB}^{\prime}\right.$ in Figure 5) when the $\mathrm{Cu}$ atom which is removed is linked to the surface oxygen $\mathrm{H}$-bonded with the molecule. This defect, indeed, yields to structural changes in the monodentate coordination, with strengthening of the covalent bond between the surface oxygen and the proton $(1.01 \AA$ vs. $1.10 \AA$ in Table 2) and weakening of the $-\mathrm{COO}-\mathrm{H}$ bond (1.69 $\AA$ vs. $1.37 \AA$ ). The $\mathrm{O}$ atom, loosing the coordination to the $\mathrm{Cu}$, now can strongly bind to the proton of the $-\mathrm{COOH}$ anchoring group and, if a bidentate $\mathrm{BB}-\mathrm{Cr}-\mathrm{Cr}$ guess structure is created, by rotation of the $\mathrm{COO}$ anchoring, the proton is not transferred back to the molecule after optimization, resulting in the highly stable bidentate form shown in Figure 5. Notably, this configuration turns out to be the most stable one in gas phase, with a binding energies of $-2.19 \mathrm{eV}$, among the ones optimized on both clean and defective $\mathrm{CuCrO}_{2}$ surfaces (Table 3). The corresponding dissociative monodentate, $\mathrm{V}_{1}^{R} \mathrm{M}$, as it could be expected, is slightly less stable in vacuo $(-2.06 \mathrm{eV})$ but becomes isoenergetic to the $\mathrm{BB}^{\prime}$ mode in solution, where the calculated adsorption energy is of about $-1.80 \mathrm{eV}$. This defect position, therefore, remarkably stabilizes the carboxylic anchoring to the metal oxide surface, in both a bidentate and monodentate-deprotonated mode. The others defect positions, on the other hand, do not significantly affect the adsoprtion mechanism and energetics of the monodentate form, that remains around $-1.60 /-1.35 \mathrm{eV}$ in gas phase/solution. Concerning the 
bidentate structures, also in this case, a $\mathrm{Cu}$ vacancy on the first layer on the right side, that is close to the surface oxygens bound to the $\mathrm{Cr}$ atoms coordinating the molecule, induce a slight stabilization of the adsorption energy (about $0.2 \mathrm{eV}$ ) associated to a ca. $0.1 \AA$ shortening in the the $\mathrm{COO}-\mathrm{Cr}$ bonds. These results thus suggest that surface $\mathrm{Cu}$ vacancies promote stabilization of bidentate-anchoring modes which are less likely to occur on the clean surface. The calculated adsorption energies are comparable in magnitude with the ones calculated for the bidentate bridging carboxylic anchoring on $\mathrm{NiO}$ and $\mathrm{TiO}_{2},{ }^{27,32}$ and the possibility of having a bidentate coordination might be beneficial for the electronic coupling and the interfacial electron transfer processes. ${ }^{66-69}$

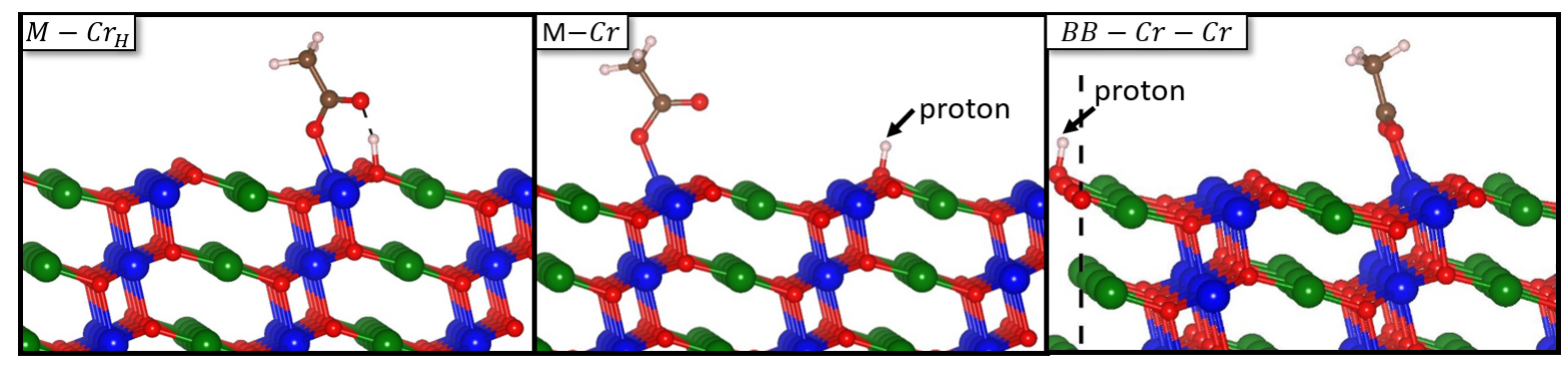

Figure 4: Optimized structures of the $\mathrm{CH}_{3}-\mathrm{COOH}$ anchoring group on the $\mathrm{CuCrO}_{2}(012)$ surface. Labels according to the anchoring mode [mondodentate $(\mathrm{M})$ and bidentate bridging (BB)] and to the surface atoms involved in the adsorption process. Sub index " $H$ " indicates $\mathrm{H}$-bonding (dashed line) between the $\mathrm{OH}$ group and the surface oxygen atom upon relaxation in $\mathrm{M}$ cases. Color legend: $\mathrm{Cu}$ (green), $\mathrm{Cr}$ (blue), $\mathrm{O}$ (red), $\mathrm{C}$ (brown), and $\mathrm{H}$ (light pink). 
Table 2: Selected optimized (PBE+U+D2) structural parameters (units in $\AA$ ) for $\mathrm{CH}_{3}-\mathrm{COOH}$ anchored on clean and defective $\mathrm{CuCrO}_{2}(012)$ in their different adsorption modes.

\begin{tabular}{|c|c|c|c|c|c|c|}
\hline \multirow{2}{*}{ Anchoring mode } & $\mathrm{d}_{C-O 1}$ & $\mathrm{~d}_{C-O 2}$ & $\mathrm{~d}_{O 2-H}$ & $\mathrm{~d}_{O 1-C r}$ & $\mathrm{~d}_{O 2-C r}$ & $\mathrm{~d}_{H-O s}$ \\
\hline \hline Isolated molecule & 1.22 & 1.37 & 0.98 & & & \\
\hline \multicolumn{7}{|c|}{ Clean CuCrO $(012)$} \\
\hline $\mathrm{M}-C r_{H}$ & 1.29 & 1.27 & 1.37 & 2.03 & & 1.10 \\
\hline $\mathrm{M}-\mathrm{Cr}$ & 1.23 & 1.32 & & & 1.97 & \\
\hline $\mathrm{BB}-\mathrm{Cr}-\mathrm{Cr}$ & 1.28 & 1.28 & & 2.05 & 2.05 & \\
\hline \multicolumn{7}{|c|}{ Defective CuCrO $(012)$} \\
\hline $\mathrm{V}_{1}^{L} \mathrm{M}$ & 1.28 & 1.28 & 1.34 & 2.03 & & 1.12 \\
\hline $\mathrm{V}_{1}^{R} \mathrm{M}$ & 1.30 & 1.25 & 1.69 & 1.99 & & 1.01 \\
\hline $\mathrm{V}_{2}^{L} \mathrm{M}$ & 1.29 & 1.27 & 1.38 & 2.03 & & 1.10 \\
\hline $\mathrm{V}_{2}^{R} \mathrm{M}$ & 1.29 & 1.27 & 1.41 & 2.02 & & 1.09 \\
\hline $\mathrm{V}_{1 H}^{R} \mathrm{BB}$ & 1.29 & 1.28 & & 2.03 & 2.04 & \\
\hline $\mathrm{V}_{1}^{L} \mathrm{BB}$ & 1.28 & 1.28 & & 2.02 & 2.02 & \\
\hline $\mathrm{V}_{1}^{R} \mathrm{BB}$ & 1.28 & 1.28 & & 2.04 & 2.04 & \\
\hline $\mathrm{V}_{2}^{L} \mathrm{BB}$ & 1.28 & 1.28 & & 2.05 & 2.05 & \\
\hline $\mathrm{V}_{2}^{R} \mathrm{BB}$ & 1.27 & 1.28 & & 2.09 & 2.04 & \\
\hline
\end{tabular}

Table 3: Calculated adsorption energies, $\Delta \mathrm{E}_{a d s}(\mathrm{eV})$ for $\mathrm{CH}_{3}-\mathrm{COOH}$ anchored on clean and defective $\mathrm{CuCrO}_{2}(012)$ in their different adsorption modes calculated at the DFT PBE+U+D2 level of theory in gas phase, and in implicit solution (water and acetonitrile)

\begin{tabular}{|c|c|c|c|}
\hline \multirow{2}{*}{$\begin{array}{c}\text { Anchoring } \\
\text { modes }\end{array}$} & Gas Phase & Water & Acetonitrile \\
\cline { 2 - 4 } & \multicolumn{3}{|c|}{$\Delta \mathrm{E}_{\text {ads }}$} \\
\hline \multicolumn{4}{|c|}{ Clean $\mathrm{CuCrO} \mathrm{O}_{2}(012)$} \\
\hline $\mathrm{M}-\mathrm{Cr}_{H}$ & -1.66 & -1.33 & -1.38 \\
\hline $\mathrm{M}-\mathrm{Cr}$ & -0.16 & -0.53 & -0.51 \\
\hline $\mathrm{BB}-\mathrm{Cr}-\mathrm{Cr}$ & -1.36 & -1.37 & -1.40 \\
\hline \multicolumn{4}{|c|}{ Defective CuCrO $\mathrm{O}_{2}(012)$} \\
\hline $\mathrm{V}_{1}^{L} \mathrm{M}$ & -1.58 & -1.26 & -1.31 \\
\hline $\mathrm{V}_{1}^{R} \mathrm{M}$ & -2.06 & -1.78 & -1.82 \\
\hline $\mathrm{V}_{2}^{L} \mathrm{M}$ & -1.64 & -1.33 & -1.38 \\
\hline $\mathrm{V}_{2}^{R} \mathrm{M}$ & -1.67 & -1.36 & -1.40 \\
\hline $\mathrm{V}_{1 H}^{R} \mathrm{BB}$ & -2.19 & -1.77 & -1.84 \\
\hline $\mathrm{V}_{1}^{L} \mathrm{BB}$ & -1.23 & -1.23 & -1.25 \\
\hline $\mathrm{V}_{1}^{R} \mathrm{BB}$ & -1.59 & -1.45 & -1.49 \\
\hline $\mathrm{V}_{2}^{L} \mathrm{BB}$ & -1.37 & -1.36 & -1.39 \\
\hline $\mathrm{V}_{2}^{R} \mathrm{BB}$ & -1.25 & -1.27 & -1.30 \\
\hline
\end{tabular}




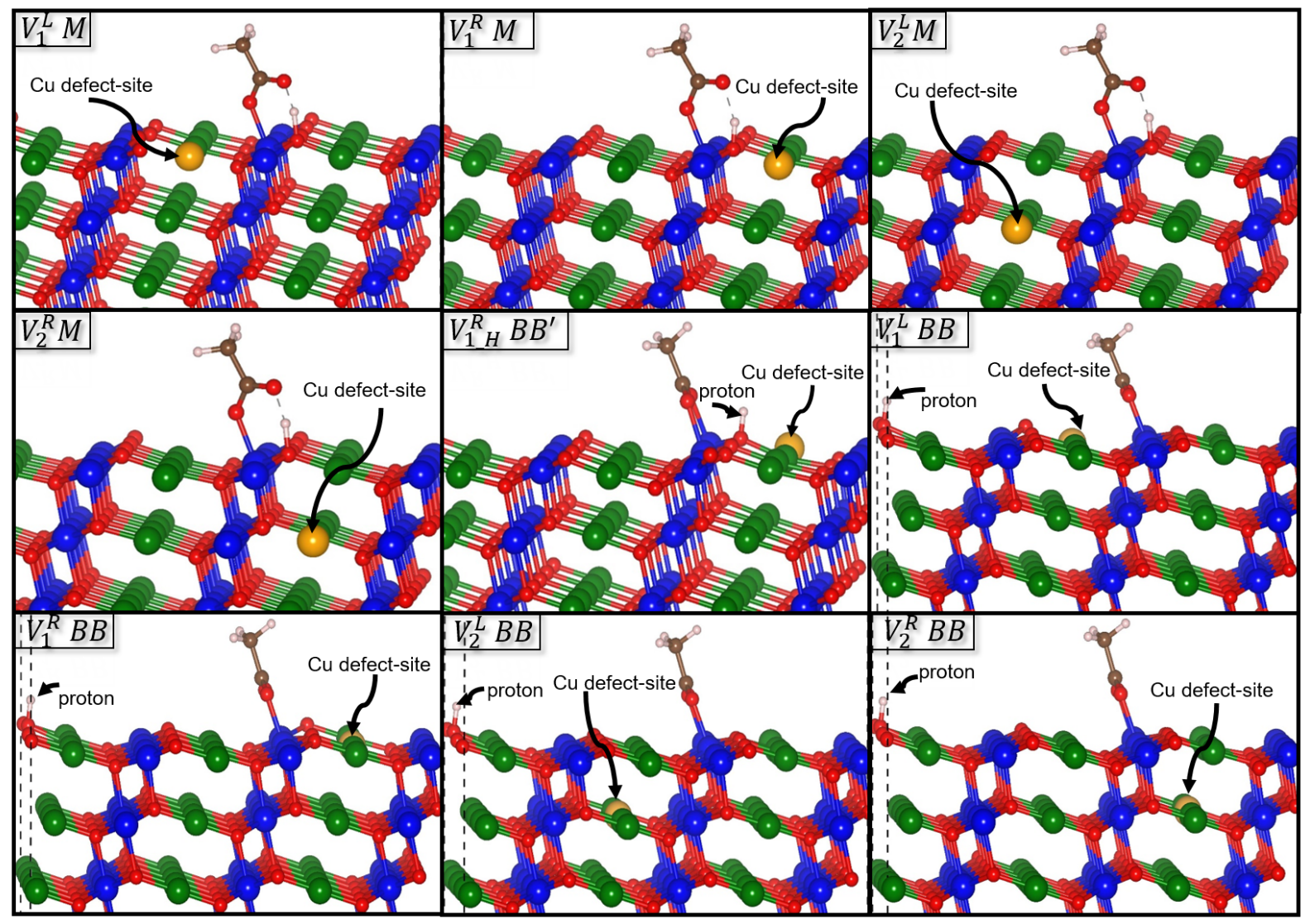

Figure 5: Formation of a single atom $\mathrm{Cu}$-vacancy around the adsorbed anchoring $\mathrm{CH}_{3}-\mathrm{COOH}$ molecule on the top two surface layers $\mathrm{CuCrO}_{2}(012)$. The label $\mathrm{V}_{1 / 2}^{L / R} \mathrm{M} / \mathrm{BB}$ represents the $\mathrm{Cu}$-vacancy site where $1 / 2$ is the first/second layer, $\mathrm{L} / \mathrm{R}$ is the left/right to the anchored site and $\mathrm{M} / \mathrm{BB}$ represent monodentate/bidentate-bridging mode. The yellow highlighted site pointed with arrow symbol represents the $\mathrm{Cu}$ defect-site.

\subsection{Phosphonic acid on (012) $\mathrm{CuCrO}_{2}$}

The possible anchoring modes of the phosphonic acid on the $\mathrm{CuCrO}_{2}(012)$ surface, according to the degree of deprotonation, are depicted in Figure 6. In principle, the neutral form, $-\mathrm{PO}_{3} \mathrm{H}_{2}$, can form one covalent bond with $\mathrm{Cr}\left(\mathrm{M}-\mathrm{Cr}_{2 H}\right)$ or $\mathrm{Cu}\left(\mathrm{M}-\mathrm{Cu}_{2 H}\right)$, where the " $2 \mathrm{H}$ " notation indicates that the two protons are retained by the molecule and can form H-bonds with the surface oxygen atoms. The monodeprotonated form, $\left[-\mathrm{PO}_{3} \mathrm{H}\right]^{-}$, can bind in a bidentate bridging fashion to two $\mathrm{Cr}\left(\mathrm{BB}-\mathrm{Cr}-\mathrm{Cr}_{H}\right)$ or two $\mathrm{Cu}\left(\mathrm{BB}-\mathrm{Cu}-\mathrm{Cu}_{H}\right)$, as well as to a $\mathrm{CuCr}$ pair $\left(\mathrm{BB}-\mathrm{Cu}-\mathrm{Cr}_{H}\right)$. Finally, if both the protons are transferred to the surface, $\left[-\mathrm{PO}_{3}\right]^{2-}$, in princi- 
ple, two tridentate modes are possible $(\mathrm{T}-\mathrm{Cu}-\mathrm{Cu}-\mathrm{Cr}$ and $\mathrm{T}-\mathrm{Cu}-\mathrm{Cr}-\mathrm{Cr})$. Note that a tridentate coordination of the phosphonic group was found to be stabilized at room temperature in water on the (100) NiO surface. ${ }^{32}$ As discussed above for the carboxylic group, also in this case, for the $\mathrm{BB}$ and $\mathrm{T}$ modes, the $\mathrm{H}$ atoms have been attached to surface oxygen atoms as far as possible from the anchoring group.

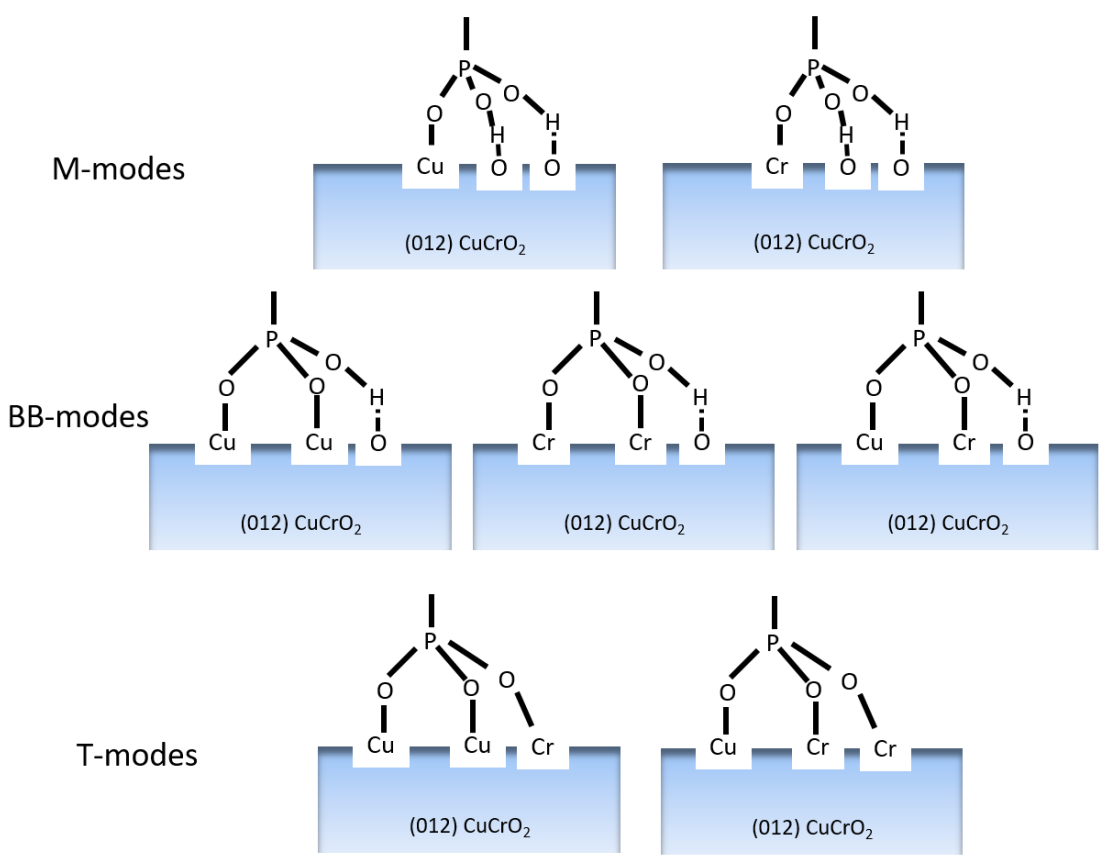

Figure 6: Schematic representation of all possible binding modes for a phosphonic acid ($\left.\mathrm{PO}_{3} \mathrm{H}_{2}\right)$ anchoring on the $\mathrm{CuCrO}_{2}(012)$ surface: monodentate $(\mathrm{M})$ modes $\left(\mathrm{M}^{-\mathrm{Cu}_{2} \mathrm{H}}\right.$ and $\mathrm{M}-$ $\mathrm{Cr}_{2 H}$ ), bidentate bridging (BB) modes (BB-Cu-Cu, $\mathrm{BB}-\mathrm{Cr}-\mathrm{Cr}_{H}$ and $\left.\mathrm{BB}-\mathrm{Cu}-\mathrm{Cr}_{H}\right)$ and tridentate $(\mathrm{T})$ modes $(\mathrm{T}-\mathrm{Cu}-\mathrm{Cu}-\mathrm{Cr}$ and $\mathrm{T}-\mathrm{Cu}-\mathrm{Cr}-\mathrm{Cr})$.

The only three stable adsorption configurations obtained after full structural relaxation of the considered guess structures are shown in Figure 7. As discussed in the previous section for $-\mathrm{COOH}$, the chemical grafting to $\mathrm{Cu}$ sites is unstable and, upon relaxation, $\mathrm{M}-\mathrm{Cu}_{2 H}$ and B-Cu-Cu${ }_{H}$ were converted into $\mathrm{M}-\mathrm{Cr}_{2 H}$ and $\mathrm{BB}-\mathrm{Cr}-\mathrm{Cr}_{H}$, respectively. The corresponding optimized structural parameters together with the binding energies $\left(\Delta \mathrm{E}_{a d s}\right)$ of all the stable modes are listed in Table 4 and Table 5, respectively. Monodentate, $\mathrm{M}_{-} \mathrm{Cr}_{2 H}$, and bidentate, BB-Cr$\mathrm{Cr}_{H}$, anchoring modes are, interestingly, very close in energy in both gas phase (-2.19 and -2.11 $\mathrm{eV}$, respectively) and solution (-1.73/-1.82 and $-1.86 /-1.92 \mathrm{eV}$ in water/ACN, respectively) and, 
as expected, their adsorption energy significantly exceeds (ca. $0.5 \mathrm{eV}$ ) that calculated for the carboxylic anchoring group (Table 3). This magnitude of binding energy is more than two-fold in magnitude with respect to the monodentate $\mathrm{M}^{-\mathrm{Cr}_{2 H}}$ mode occurred on the $\mathrm{NiO}(001)$ and $\mathrm{CuGaO}_{2}$ (012) surface ${ }^{37}$ when Grimme's correction was taken into consideration. Structural relaxation of the tridentate T-Cr-Cr-Cu configuration (Figure 6) clearly ended up in a weakly stable dissociated bidentate $\mathrm{Cr}-\mathrm{Cr}$ structure (BB-Cr-Cr), due to the impossibility to keep the coordination to the $\mathrm{Cu}$ atom. Inclusion of solvent dielectric screening stabilizes this configuration, which, however, with a calculated adsorption energy of about $-0.8 \mathrm{eV}$ (at the PBE+U+D2 level) is not likely to occur.

Moving to the reduced (012) surface (Figure 8) and following the same scheme of Cu vacancies creation for both monodentate $\left(\mathrm{M}-\mathrm{Cr}_{2 H}\right)$ and bidentate bridging $\left(\mathrm{BB}-\mathrm{Cr}-\mathrm{Cr}{ }_{H}\right)$ modes discussed in the previous section, we again observe stabilization of the molecular monodentate mode when the defect is created on the right side and on the top layer $\left(\mathrm{V}_{1}^{R} \mathrm{M}\right.$ in Figure 8$)$. The adsorption energy increases from -2.19 to $-2.51 \mathrm{eV}$ in gas phase and from about -1.8 to $-2.3 \mathrm{eV}$ in solution, as a consequence of peculiar structural rearrangements similar to the ones discussed above for the carboxylic group. As shown by the optimized bond distances reported in Table 4, one of the two strong $\mathrm{H}$-bonds $\left(\mathrm{H}_{1 / 2}-\mathrm{O}_{s} 1.49 \AA\right)$, the one corresponding to the oxygen contiguous to the $\mathrm{Cu}$ vacancy, becomes a true covalent bond (1.02 $\AA$ ) with consequent deprotonation of the molecule $\left(\mathrm{O}_{2}-\mathrm{H}_{2}\right.$ from 1.06 to $1.65 \AA$ ). This rearrangement is somewhat counterbalanced on the other $\mathrm{OH}$ group, by shortening of the covalent $\mathrm{O}_{1}-\mathrm{H}_{1}$ bond (from 1.06 to $1.01 \AA$ ) and elongation of the $\mathrm{O}_{s}-\mathrm{H}_{1}$ bond (from 1.49 to $1.71 \AA$ ). Starting from this monodentate deprotonated structure, a bidentate mode can be easily stabilized, $\mathrm{V}_{1 \_H}^{R} \mathrm{BB}$, with a gain of $0.4 \mathrm{eV}$ in the binding energy (-2.91 and ca. $-2.70 \mathrm{eV}$ in gas pahse and solution, respectively, Table 5). Interestingly, this is by far the most stable adsorption configuration predicted for the phosphonic acid, suggesting again that surface $\mathrm{Cu}$ defects promote a stable bidentate coordination to the $\mathrm{CuCrO}_{2}$ surface. On the other hand, the deprotonated bidentate anchoring, $\mathrm{BB}-\mathrm{Cr}-\mathrm{Cr} H$, is not significantly stabilized/destabilized by neighboring $\mathrm{Cu}$ vacancies, with only a negligible 0.05 $\mathrm{eV}$ increase in the binding energy when the defect is on the right side and on the top surface layer $\left(\mathrm{V}_{1}^{R} \mathrm{BB}\right.$ in Table 5). 


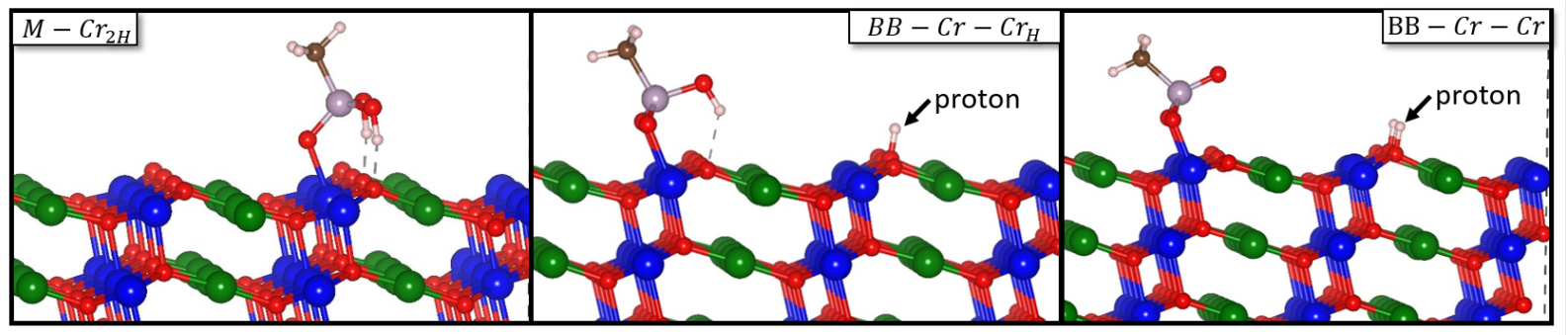

Figure 7: Optimized structures of the $\mathrm{CH}_{3}-\mathrm{PO}_{3} \mathrm{H}_{2}$ anchoring group on $\mathrm{CuCrO}_{2}(012)$ surface. Labels according to the anchoring mode [mondodentate (M) and bidentate bridging (BB)] and to the surface atoms involved in the adsorption process. Sub index "H" indicates $\mathrm{H}$ bonding (dashed line) between the $\mathrm{OH}$ group and surface oxygen atom upon relaxation in $\mathrm{M}$ cases. Color legend: $\mathrm{Cu}$ (green), $\mathrm{Cr}$ (blue), $\mathrm{O}$ (red), $\mathrm{C}$ (brown), $\mathrm{P}$ (lavender) and $\mathrm{H}$ (light pink).

Table 4: Selected optimized (PBE+U+D2) structural parameters (units in $\AA$ ) for $\mathrm{CH}_{3} \mathrm{PO}_{3} \mathrm{H}_{2}$ anchored on clean and defective $\mathrm{CuCrO}_{2}(012)$ in different adsorption modes.

\begin{tabular}{|c|c|c|c|c|c|c|c|c|c|}
\hline \multirow{2}{*}{$\begin{array}{l}\text { Anchoring } \\
\text { modes }\end{array}$} & \multicolumn{9}{|c|}{ Bond distances $(\AA)$} \\
\hline & $\mathrm{d}_{P-O 1}$ & $\mathrm{~d}_{P-O 2}$ & $\mathrm{~d}_{P-O 3}$ & $\mathrm{~d}_{O 1-H 1}$ & $\mathrm{~d}_{O 2-H 2}$ & $\mathrm{~d}_{O 3-C r}$ & $\mathrm{~d}_{O 1-C r}$ & $\mathrm{~d}_{H 1-O s}$ & $\mathrm{~d}_{H 2-O s}$ \\
\hline $\begin{array}{l}\text { Isolated } \\
\text { molecule }\end{array}$ & 1.62 & 1.61 & 1.48 & 0.98 & 0.98 & & & & \\
\hline \multicolumn{10}{|c|}{ Clean $\mathrm{CuCrO}_{2}(012)$} \\
\hline $\mathrm{M}-\mathrm{Cr}_{2 H}$ & 1.58 & 1.58 & 1.54 & 1.06 & 1.06 & 2.04 & & 1.49 & 1.49 \\
\hline BB-Cr-Cr ${ }_{H}$ & 1.54 & 1.60 & 1.54 & & 1.01 & 2.04 & 2.04 & & 1.77 \\
\hline $\mathrm{BB}-\mathrm{Cr}-\mathrm{Cr}$ & 1.51 & 1.58 & 1.58 & & & 1.97 & 1.97 & & \\
\hline \multicolumn{10}{|c|}{ Defective $\mathrm{CuCrO}_{2}(012)$} \\
\hline $\mathrm{V}_{1}^{L} \mathrm{M}$ & 1.58 & 1.58 & 1.53 & 1.06 & 1.06 & 2.04 & & 1.50 & 1.50 \\
\hline $\mathrm{V}_{1}^{R} \mathrm{M}$ & 1.61 & 1.51 & 1.57 & 1.01 & 1.65 & 1.99 & & 1.71 & 1.02 \\
\hline $\mathrm{V}_{2}^{L} \mathrm{M}$ & 1.58 & 1.58 & 1.54 & 1.06 & 1.06 & 2.05 & & 1.49 & 1.49 \\
\hline $\mathrm{V}_{2}^{R} \mathrm{M}$ & 1.58 & 1.58 & 1.53 & 1.06 & 1.06 & 2.08 & & 1.50 & 1.50 \\
\hline $\mathrm{V}_{1 H}^{R} \mathrm{BB}$ & 1.57 & 1.52 & 1.59 & & 1.76 & 1.99 & 1.97 & & 1.01 \\
\hline $\mathrm{V}_{1}^{L} \mathrm{BB}$ & 1.55 & 1.61 & 1.54 & & 1.01 & 2.03 & 2.04 & & 1.78 \\
\hline $\mathrm{V}_{1}^{R} \mathrm{BB}$ & 1.54 & 1.68 & 1.54 & & 1.01 & 1.54 & 1.54 & & 1.77 \\
\hline $\mathrm{V}_{2}^{L} \mathrm{BB}$ & 1.54 & 1.60 & 1.54 & & 1.01 & 2.05 & 2.05 & & 1.76 \\
\hline $\mathrm{V}_{2}^{R} \mathrm{BB}$ & 1.54 & 1.61 & 1.55 & & 1.01 & 2.04 & 2.08 & & 1.79 \\
\hline
\end{tabular}


Table 5: Calculated adsorption energies, $\Delta \mathrm{E}_{a d s}(\mathrm{eV})$ for $\mathrm{CH}_{3}-\mathrm{PO}-(\mathrm{OH})_{2}$ anchored on clean and defective $\mathrm{CuCrO}_{2}$ (012) in their different adsorption modes calculated at the DFT $\mathrm{PBE}+\mathrm{U}+\mathrm{D} 2$ level of theory in gas phase, and in implicit solution (water and acetonitrile)

\begin{tabular}{|c|c|c|c|}
\hline \multirow{2}{*}{$\begin{array}{c}\text { Anchoring } \\
\text { modes }\end{array}$} & Gas Phase & Water & Acetonitrile \\
\cline { 2 - 4 } & \multicolumn{3}{|c|}{$\Delta \mathrm{E}_{\text {ads }}$} \\
\hline \multicolumn{4}{|c|}{ Clean $\mathrm{CuCrO} \mathrm{Cr}_{2}(012)$} \\
\hline${\mathrm{M}-\mathrm{Cr}_{2 H}}^{\prime}$ & -2.19 & -1.73 & -1.82 \\
\hline $\mathrm{BB}-\mathrm{Cr}-\mathrm{Cr}_{H}$ & -2.11 & -1.86 & -1.92 \\
\hline $\mathrm{BB}-\mathrm{Cr}-\mathrm{Cr}$ & -0.30 & -0.84 & -0.82 \\
\hline \multicolumn{4}{|c|}{ Defective CuCrO ${ }_{2}(012)$} \\
\hline $\mathrm{V}_{1}^{L} \mathrm{M}$ & -2.09 & -1.67 & -1.75 \\
\hline $\mathrm{V}_{1}^{R} \mathrm{M}$ & -2.51 & -2.26 & -2.33 \\
\hline $\mathrm{V}_{2}^{L} \mathrm{M}$ & -2.17 & -1.72 & -1.81 \\
\hline $\mathrm{V}_{2}^{R} \mathrm{M}$ & -1.99 & -1.59 & -1.67 \\
\hline $\mathrm{V}_{1 H}^{R} \mathrm{BB}$ & -2.91 & -2.72 & -2.79 \\
\hline $\mathrm{V}_{1}^{L} \mathrm{BB}$ & -1.80 & -1.78 & -1.83 \\
\hline $\mathrm{V}_{1}^{R} \mathrm{BB}$ & -2.16 & -1.93 & -2.01 \\
\hline $\mathrm{V}_{2}^{L} \mathrm{BB}$ & -1.95 & -1.85 & -1.91 \\
\hline $\mathrm{V}_{2}^{R} \mathrm{BB}$ & -1.80 & -1.74 & -1.80 \\
\hline
\end{tabular}




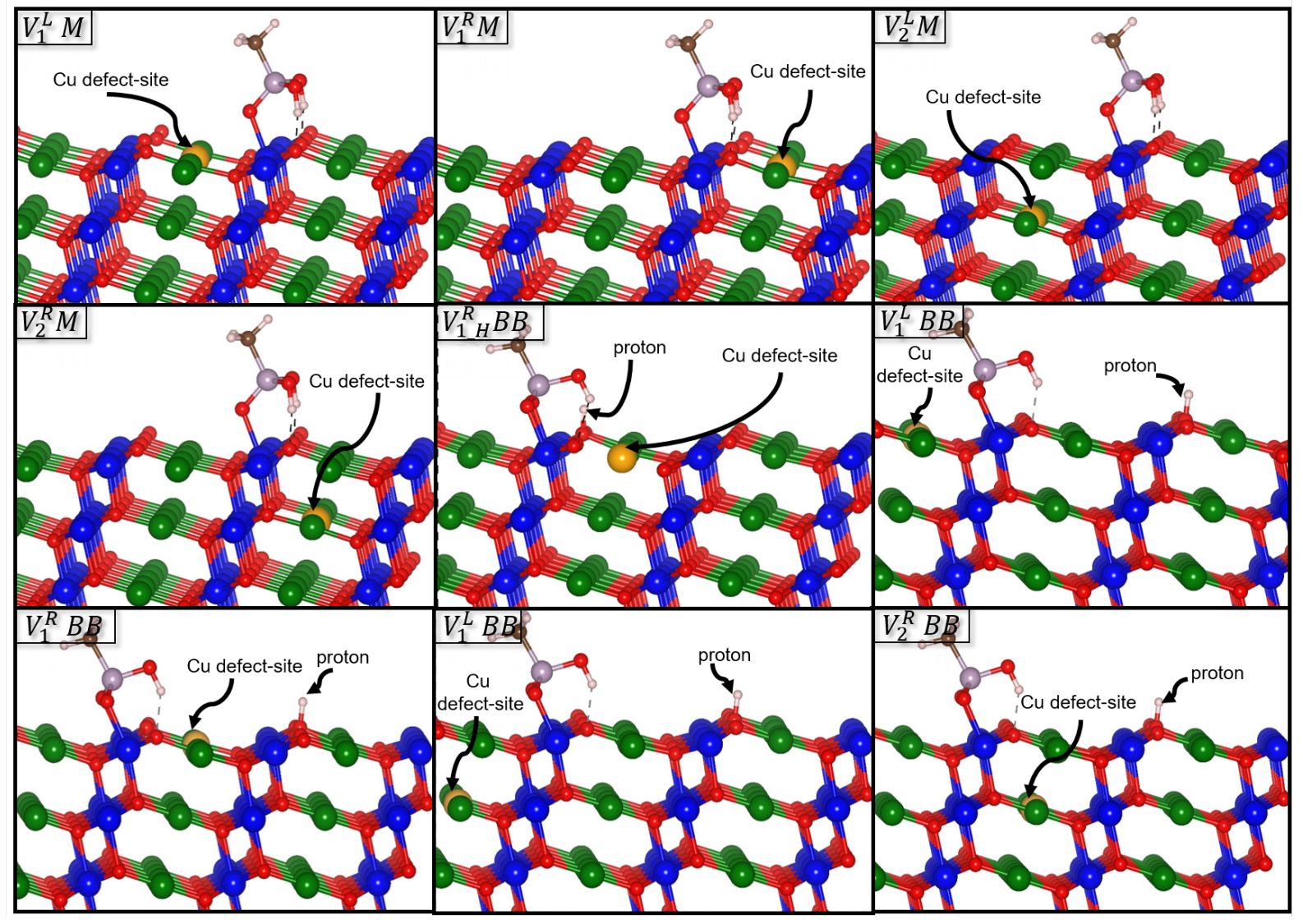

Figure 8: Formation of the $\mathrm{Cu}$ mono-vacancy around the adsorbed anchoring $\mathrm{CH}_{3}-\mathrm{PO}_{3} \mathrm{H}_{2}$ molecule on the top two surface layers $\mathrm{CuCrO}_{2}(012)$. The label $\mathrm{V}_{1 / 2}^{L / R} \mathrm{M} / \mathrm{BB}$ represents the $\mathrm{Cu}$-vacancy site where $1 / 2$ is the first/second layer, $\mathrm{L} / \mathrm{R}$ is the left/right to the anchored site and $\mathrm{M} / \mathrm{BB}$ represent monodentate/bidentate-bridging mode. The yellow highlighted site pointed with arrow symbol represents the $\mathrm{Cu}$ defect-site.

\section{Conclusion}

Here we have investigated the possibility of using the $\mathrm{CuCrO}_{2}$ delafossite oxide as an alternative material to $\mathrm{NiO}$ for p-type DSSCs. We have modeled the anchoring mechanism of the carboxylic and phosphonic groups as well as their stability, in vacuo and implicit solution, on pristine and defective $\left(\mathrm{Cu}^{+}\right.$vacancies $) \mathrm{CuCrO}_{2}$ (012) surface models. To this aim, DFT calculations at the $\mathrm{PBE}, \mathrm{PBE}+\mathrm{D} 2, \mathrm{PBE}+\mathrm{U}$ and $\mathrm{PBE}+\mathrm{U}+\mathrm{D} 2$ level of theory have been carried out, systematically considering all the possible adsorbed configurations for each protonation state of the acidic groups. Overall, the present results indicate that, the two anchoring groups stably 
adsorb on the $\mathrm{CuCrO}_{2}$ (012) surface, with comparable binding energies, and even larger, to that calculated for $\mathrm{NiO}$. The phosphonic group is found, in line with the results obtained on other metal oxide surfaces, to have a larger adsorption energy. More interestingly, while monodentate adsorption is preferred on clean surfaces, unless the protons are forced to remain on the substrate by putting them far from the molecule, bidentate bridging modes are largely stabilized on defective slabs, when the $\mathrm{Cu}^{+}$vacancy is adjacent to the surface $\mathrm{O}$ atom interacting by a H-bond with the molecule. This particular defect position allows the surface oxygen to covalently bind the proton coming from the molecule, resulting in the deprotonation of the anchoring group and in the consequent stabilization on a bidentate coordination to two $\mathrm{Cr}$ sites. The possibility to form bidentate linking between the dye and the metal oxide surface has been shown to be beneficial for the efficiency of the interfacial electron transfer processes and thus for the overall DSSC performances. These findings, providing for the first time atomistic insights on the mechanism of dye adsorption on $\mathrm{CuCrO}_{2}(012)$ surfaces, might indicate possible routes for the optimization and the selection of alternative anchoring groups for $\mathrm{Cu}(\mathrm{I})$-delafossite- based DSSCs.

\section{Supporting Information}

Optimized structures and atom labeling of $\mathrm{CH}_{3}-\mathrm{COOH}$ and $\mathrm{CH}_{3}-\mathrm{PO}_{3} \mathrm{H}_{2}$. Total and partial density of states (DOS, PDOS) of the pristine and defective surface slab. Bader's charges on some representative $\mathrm{Cr}$ atoms for the pristine and defective slabs. $\mathrm{PBE}, \mathrm{PBE}+\mathrm{U}$ and $\mathrm{PBE}+\mathrm{D} 2$ adsorption energies calculated in vacuo for the carboxylic and the phosponic acid groups on both the clean and defective surfaces.

\section{Acknowledgment}

This work has been carried out in the framework of the ANR JCJC HELIOSH2 project (ANR17-CE05-0007-01). HPC resources from the mésocentre EXPLOR of Université de Lorraine and LPCT local computational resources are greatly acknowledged. 


\section{References}

[1] Hagfeldt, A.; Boschloo, G.; Sun, L.; Kloo, L.; Pettersson, H. Dye-sensitized solar cells Chem. Rev. 2010, 110, 6595-6663.

[2] Brian O’Regan and Michael Grätzel A low-cost, high-efficiency solar cell based on dyesensitized colloidal $\mathrm{TiO}_{2}$ films Nature 1991, 353, 737-740.

[3] Kakiage, K.; Aoyama, Y.; Yano, T.; Oya, K.; Fujisawa, J. I.; Hanaya, M. Highly-efficient dye-sensitized solar cells with collaborative sensitization by silyl-anchor and carboxyanchor dyes Chem. Commun. 2015, 51, 15894-15897.

[4] He, J.; Lindström, H.; Hagfeldt, A.; Lindquist, S. E. Dye-Sensitized Nanostructured pType Nickel Oxide Film as a Photocathode for a Solar Cell J. Phys. Chem. B 1999, 103, 8940-8943.

[5] Nattestad, A.; Mozer, A. J.; Fischer, M. K.; Cheng, Y. B.; Mishra, A.; Bäuerle, P.; Bach, U. Highly efficient photocathodes for dye-sensitized tandem solar cells Nat. Mater. 2010, $9,31-35$.

[6] Odobel, F.; Pellegrin, Y. Recent advances in the sensitization of wide-band-gap nanostructured p-type semiconductors. photovoltaic and photocatalytic applications J. Phys. Chem. Lett. 2013, 4, 2551-2564.

[7] Perera, I. R.; Daeneke, T.; Makuta, S.; Yu, Z.; Tachibana, Y.; Mishra, A.; Bäuerle, P.; Ohlin, C. A.; Bach, U.; Spiccia, L. Application of the tris(acetylacetonato)iron(III)/(II) redox couple in p-type dye-sensitized solar cells Angew. Chem. Int. Ed. 2015, 54, 37583762.

[8] Mori, S.; Fukuda, S.; Sumikura, S.; Takeda, Y.; Tamaki, Y.; Suzuki, E.; Abe, T. Chargetransfer processes in dye-sensitized NiO solar cells J. Phys. Chem. C 2008, 112, 1613416139. 
[9] Anta, J. A.; Guillén, E.; Tena-Zaera, R. ZnO-based dye-sensitized solar cells J. Phys. Chem. C 2012, 116, 11413-11425.

[10] Yu, M.; Draskovic, T. I.; Wu, Y. Cu(I)-based delafossite compounds as photocathodes in p-type dye-sensitized solar cells Phys. Chem. Chem. Phys. 2014, 16, 5026-5033.

[11] Ueda, K.; Inouse, S.; Hirose, S.; Kawazoe, H.; Hosono, H. Transparent p -type semiconductor : LaCuOS layered oxysulfide Appl. Phys. Lett. 2000, 77, 2701-2703.

[12] Renaud, A.; Cario, L.; Pellegrin, Y.; Blart, E.; Boujtita, M.; Odobel, F.; Jobic, S. The first dye-sensitized solar cell with p-type LaOCuS nanoparticles as a photocathode RSC Adv. 2015, 5, 60148-60151.

[13] Shi, Z.; Lu, H.; Liu, Q.; Deng, K.; Xu, L.; Zou, R.; Hu, J.; Bando, Y.; Golberg, D.; Li, L. $\mathrm{NiCo}_{2} \mathrm{O}_{4}$ Nanostructures as a Promising Alternative for NiO Photocathodes in p-Type Dye-Sensitized Solar Cells with High Efficiency Energy Technol. 2014, 2, 517-521.

[14] Powar, S.; Xiong, D.; Daeneke, T.; Ma, M. T.; Gupta, A.; Lee, G.; Makuta, S.; Tachibana, Y.; Chen, W.; Spiccia, L.; Cheng, Y. B.; Götz, G.; Bäuerle, P.; Bach, U. Improved photovoltages for p-type dye-sensitized solar cells using $\mathrm{CuCrO}_{2}$ nanoparticles J. Phys. Chem. C 2014, 118, 16375-16379.

[15] Kaya, I. C.; Akin, S.; Akyildiz, H.; Sonmezoglu, S. Highly efficient tandem photoelectrochemical solar cells using coumarin6 dye-sensitized $\mathrm{CuCrO}_{2}$ delafossite oxide as photocathode Sol. Energy 2018, 169, 196-205.

[16] Xiong, D.; Xu, Z.; Zeng, X.; Zhang, W.; Chen, W.; Xu, X.; Wang, M.; Cheng, Y. B. Hydrothermal synthesis of ultrasmall $\mathrm{CuCrO}_{2}$ nanocrystal alternatives to $\mathrm{NiO}$ nanoparticles in efficient p-type dye-sensitized solar cells J. Mater. Chem. 2012, 22, 24760-24768.

[17] Creissen, C. E.; Warnan, J.; Antón-García, D.; Farré, Y.; Odobel, F.; Reisner, E. Inverse Opal $\mathrm{CuCrO}_{2}$ Photocathodes for $\mathrm{H}_{2}$ Production Using Organic Dyes and a Molecular Ni Catalyst ACS Catal. 2019, 9, 9530-9538. 
[18] Schiavo, E.; Latouche, C.; Barone, V.; Crescenzi, O.; Muñoz-García, A. B.; Pavone, M. An ab initio study of Cu-based delafossites as an alternative to nickel oxide in photocathodes: Effects of Mg-doping and surface electronic features Phys. Chem. Chem. Phys. 2018, 20, 14082-14089.

[19] Favereau, L.; Pellegrin, Y.; Hirsch, L.; Renaud, A.; Planchat, A.; Blart, E.; Louarn, G.; Cario, L.; Jobic, S.; Boujtita, M.; Odobel, F. Engineering Processes at the Interface of p-Semiconductor for Enhancing the Open Circuit Voltage in p-Type Dye-Sensitized Solar Cells Adv. Energy Mater. 2017, 7, 1601776.

[20] Renaud, A.; Chavillon, B.; Le Pleux, L.; Pellegrin, Y.; Blart, E.; Boujtita, M.; Pauporté, T.; Cario, L.; Jobic, S.; Odobel, F. $\mathrm{CuGaO}_{2}$ : a promising alternative for $\mathrm{NiO}$ in p-type dye solar cells J. Mater. Chem. 2012, 22, 14353-14356.

[21] Kawazoe, H.; Yasukawa, M.; Hyodo, H.; Kurita, M.; Yanagi, H.; Hosono, H. P-type electrical conduction in transparent thin films of $\mathrm{CuAlO}_{2}$ Nature 1997, 389, 939-942.

[22] Scanlon, D. O.; Watson, G. W. Understanding the p-type defect chemistry of $\mathrm{CuCrO}_{2} J$. Mater. Chem. 2011, 21, 3655-3663.

[23] Norton, E.; Farrell, L.; Callaghan, S. D.; McGuinness, C.; Shvets, I. V.; Fleischer, K. Xray spectroscopic studies of the electronic structure of chromium-based $\mathrm{p}$-type transparent conducting oxides Phys. Rev. B 2016, 93, 115302.

[24] Ahmadi, M.; Asemi, M.; Ghanaatshoar, M. Mg and N co-doped $\mathrm{CuCrO}_{2}$ : A record breaking p-type TCO Appl. Phys. Lett. 2018, 113, 242101.

[25] Creissen, C. E.; Warnan, J.; Reisner, E. Solar $\mathrm{H}_{2}$ generation in water with a $\mathrm{CuCrO}_{2}$ photocathode modified with an organic dye and molecular Ni catalyst Chem. Sci. 2018, 9, $1439-1447$.

[26] Benazzi, E.; Mallows, J.; Summers, G. H.; Black, F. A.; Gibson, E. A. Developing photocathode materials for p-type dye-sensitized solar cells J. Mater. Chem. C 2019, 7, 1040910445. 
[27] Pastore, M.; De Angelis, F. Computational modelling of $\mathrm{TiO}_{2}$ surfaces sensitized by organic dyes with different anchoring groups: Adsorption modes, electronic structure and implication for electron injection/recombination Phys. Chem. Chem. Phys. 2012, 14, 920928.

[28] Pastore, M.; De Angelis, F. Modeling materials and processes in dye-sensitized solar cells: Understanding the mechanism, improving the efficiency; Beljonne, D.; Cornil, J., Eds.; Springer Berlin Heidelberg: Berlin, Heidelberg, 2014; pp 151-236.

[29] Pastore, M.; De Angelis, F. First-principles modeling of a dye-sensitized TiO2/IrO2 photoanode for water oxidation J. Am. Chem. Soc. 2015, 137, 5798-5809.

[30] Nilsing, M.; Lunell, S.; Persson, P.; Ojamäe, L. Phosphonic acid adsorption at the TiO2 anatase (101) surface investigated by periodic hybrid HF-DFT computations Surface Science 2005, 582, 49-60.

[31] Ambrosio, F.; Martsinovich, N.; Troisi, A. Effect of the anchoring group on electron injection: Theoretical study of phosphonated dyes for dye-sensitized solar cells J. Phys. Chem. C 2012, 116, 2622-2629.

[32] Piccinin, S.; Rocca, D.; Pastore, M. Role of Solvent in the Energy Level Alignment of Dye-Sensitized NiO Interfaces J. Phys. Chem. C 2017, 121, 22286-22294.

[33] Muñoz-García, A. B.; Pavone, M. Structure and energy level alignment at the dyeelectrode interface in p-type DSSCs: New hints on the role of anchoring modes from ab initio calculations Phys. Chem. Chem. Phys. 2015, 17, 12238-12246.

[34] Wykes, M.; Odobel, F.; Adamo, C.; Ciofini, I.; Labat, F. Anchoring groups for dyes in p-DSSC application: insights from DFT J. Mol. Model. 2016, 22, 289.

[35] Kontkanen, O. V.; Niskanen, M.; Hukka, T. I.; Rantala, T. T. Electronic structure of p-type perylene monoimide-based donor-acceptor dyes on the nickel oxide (100) surface: A DFT approach Phys. Chem. Chem. Phys. 2016, 18, 14382-14389. 
[36] Carella, A.; Centore, R.; Borbone, F.; Toscanesi, M.; Trifuoggi, M.; Bella, F.; Gerbaldi, C.; Galliano, S.; Schiavo, E.; Massaro, A.; Muñoz-García, A. B.; Pavone, M. Tuning optical and electronic properties in novel carbazole photosensitizers for p-type dye-sensitized solar cells Electrochim. Acta 2018, 292, 805-816.

[37] Muñoz-García, A. B.; Caputo, L.; Schiavo, E.; Baiano, C.; Maddalena, P.; Pavone, M. Ab initio study of anchoring groups for $\mathrm{CuGaO}_{2}$ delafossite-based p-type dye sensitized solar cells Front. Chem. 2019, 7, 1-13.

[38] Farrell, L.; Norton, E.; Smith, C. M.; Caffrey, D.; Shvets, I. V.; Fleischer, K. Synthesis of nanocrystalline $\mathrm{Cu}$ deficient $\mathrm{CuCrO}_{2}$-a high figure of merit p-type transparent semiconductor J. Mater. Chem. C 2015, 4, 126-134.

[39] Lunca-Popa, P.; Botsoa, J.; Bahri, M.; Crêpellière, J.; Desgardin, P.; Audinot, J. N.; Wirtz, T.; Arl, D.; Ersen, O.; Barthe, M. F.; Lenoble, D. Tuneable interplay between atomistic defects morphology and electrical properties of transparent p-type highly conductive offstoichiometric Cu-Cr-O delafossite thin films Sci. Rep. 2020, 10, 1416 —.

[40] Bredar, A. R.; Blanchet, M. D.; Comes, R. B.; Farnum, B. H. Evidence and influence of copper vacancies in p-type $\mathrm{CuGaO}_{2}$ mesoporous films ACS Appl. Energy Mater. 2019, 2 , $19-28$.

[41] Kresse, G.; Furthmüller, J. Efficiency of ab-initio total energy calculations for metals and semiconductors using a plane-wave basis set Comput. Mater. Sci. 1996, 6, 15-50.

[42] Kresse, G.; Furthmüller, J. Efficient iterative schemes for ab initio total-energy calculations using a plane-wave basis set Phys. Rev. B 1996, 54, 11169-11186.

[43] Perdew, J. P.; Burke, K.; Ernzerhof, M. Generalized Gradient Approximation Made Simple Phys. Rev. Lett. 1996, 77, 3865-3868.

[44] Blöchl, P. E. Projector augmented-wave method Phys. Rev. B 1994, 50, 17953-17979.

[45] Kresse, G.; Joubert, D. From ultrasoft potentials to the projector augmented-wave method Phys. Rev. B 1999, 59, 1758. 
[46] Dudarev, S.; Botton, G. Electron-energy-loss spectra and the structural stability of nickel oxide: An LSDA+U study Phys. Rev. B 1998, 57, 1505-1509.

[47] Rohrbach, A.; Hafner, J.; Kresse, G. Electronic correlation effects in transition-metal sulfides J. Phys. Condens. Matter 2003, 15, 979-996.

[48] Scanlon, D. O.; Walsh, A.; Morgan, B. J.; Watson, G. W.; Payne, D. J.; Egdell, R. G. Effect of $\mathrm{Cr}$ substitution on the electronic structure of $\mathrm{CuAl}_{1-x} \mathrm{Cr}_{x} \mathrm{O}_{2}$ Phys. Rev. B 2009, 79, 035101.

[49] Grimme, S. Semiempirical GGA-Type Density Functional Constructed with a LongRange Dispersion Correction J. Comput. Chem. 2006, 27, 1787-1799.

[50] Bučko, T.; Hafner, J.; Lebègue, S.; Ángyán, J. G. Improved description of the structure of molecular and layered crystals: Ab initio DFT calculations with van der Waals corrections J. Phys. Chem. A 2010, 114, 11814-11824.

[51] Mathew, K.; Kolluru, V. S.; Mula, S.; Steinmann, S. N.; Hennig, R. G. Implicit selfconsistent electrolyte model in plane-wave density-functional theory J. Chem. Phys. 2019, $151,234101$.

[52] Fishman, M.; Zhuang, H. L.; Mathew, K.; Dirschka, W.; Hennig, R. G. Accuracy of exchange-correlation functionals and effect of solvation on the surface energy of copper Phys. Rev. B 2013, 87, 245402.

[53] Poienar, M.; Damay, F.; Martin, C.; Hardy, V.; Maignan, A.; André, G. Structural and magnetic properties of $\mathrm{CuCr}_{1-x} \mathrm{Mg}_{x} \mathrm{O}_{2}$ by neutron powder diffraction Phys. Rev. B 2009, $79,014412$.

[54] Zhou, S.; Fang, X.; Deng, Z.; Li, D.; Dong, W.; Tao, R.; Meng, G.; Wang, T.; Zhu, $\mathrm{X}$. Hydrothermal synthesis and characterization of $\mathrm{CuCrO}_{2}$ laminar nanocrystals J. Cryst. Growth 2008, 310, 5375-5379. 
[55] Kimura, K.; Nakamura, H.; Ohgushi, K.; Kimura, T. Magnetoelectric control of spinchiral ferroelectric domains in a triangular lattice antiferromagnet Phys. Rev. B 2008, 78, 140401.

[56] Arnold, T.; Payne, D. J.; Bourlange, A.; Hu, J. P.; Egdell, R. G.; Piper, L. F.; Colakerol, L.; De Masi, A.; Glans, P. A.; Learmonth, T.; Smith, K. E.; Guo, J.; Scanlon, D. O.; Walsh, A.; Morgan, B. J.; Watson, G. W. X-ray spectroscopic study of the electronic structure of $\mathrm{CuCrO}_{2}$ Phys. Rev. B 2009, 79, 075102.

[57] Wang, X.; Meng, W.; Yan, Y. Electronic band structures and excitonic properties of delafossites: A GW-BSE study J. Appl. Phys. 2017, 122, 085104.

[58] Xiong, D.; Zhang, W.; Zeng, X.; Xu, Z.; Chen, W.; Cui, J.; Wang, M.; Sun, L.; Cheng, Y. B. Enhanced performance of p-type dye-sensitized solar cells based on ultrasmall Mgdoped $\mathrm{CuCrO}_{2}$ nanocrystals ChemSusChem 2013, 6, 1432-1437.

[59] Toyoda, K.; Hinogami, R.; Miyata, N.; Aizawa, M. Calculated descriptors of catalytic activity for water electrolysis anode: Application to delafossite oxides J. Phys. Chem. C 2015, 119, 6495-6501.

[60] Jiang, X. F.; Liu, X. F.; Wu, Y. Z.; Han, J. R. Exchange coupling and helical spin order in the triangular lattice antiferromagnet $\mathrm{CuCrO}_{2}$ using first principles Chin. Phys. B 2012, $21,077502$.

[61] Bansal, D.; Niedziela, J. L.; May, A. F.; Said, A.; Ehlers, G.; Abernathy, D. L.; Huq, A.; Kirkham, M.; Zhou, H.; Delaire, O. Lattice dynamics and thermal transport in multiferroic $\mathrm{CuCrO}_{2}$ Phys. Rev. B 2017, 95, 054306.

[62] Anselmi, C.; Mosconi, E.; Pastore, M.; Ronca, E.; De Angelis, F. Adsorption of organic dyes on $\mathrm{TiO}_{2}$ surfaces in dye-sensitized solar cells: Interplay of theory and experiment Phys. Chem. Chem. Phys. 2012, 14, 15963-15974. 
[63] Ito, S.; Miura, H.; Uchida, S.; Takata, M.; Sumioka, K.; Liska, P.; Comte, P.; Péchy, P.; Grätzel, M. High-conversion-efficiency organic dye-sensitized solar cells with a novel indoline dye Chem. Commun. 2008, 5194-5196.

[64] El-Zohry, A. M.; Agrawal, S.; De Angelis, F.; Pastore, M.; Zietz, B. Critical Role of Protons for Emission Quenching of Indoline Dyes in Solution and on Semiconductor Surfaces J. Phys. Chem. C 2020, 124, 21346-21356.

[65] Lunca-Popa, P.; Afonso, J.; Grysan, P.; Crêpellière, J.; Leturcq, R.; Lenoble, D. Tuning the electrical properties of the p-type transparent conducting oxide $\mathrm{Cu}_{1-x} \mathrm{Cr}_{1+x} \mathrm{O}_{2}$ by controlled annealing Sci. Rep. 2018, 8, 7216.

[66] Ronca, E.; Pastore, M.; Belpassi, L.; Tarantelli, F.; De Angelis, F. Influence of the dye molecular structure on the $\mathrm{TiO}_{2}$ conduction band in dye-sensitized solar cells: Disentangling charge transfer and electrostatic effects Energy Environ. Sci. 2013, 6, 183-193.

[67] Pastore, M.; De Angelis, F. Modeling materials and processes in dye-sensitized solar cells: understanding the mechanism, improving the efficiency. In: Beljonne D., Cornil J. (eds) Multiscale Modelling of Organic and Hybrid Photovoltaics. Topics in Current Chemistry 2013, 352, 151-236.

[68] Zhang, L.; Cole, J. M. Anchoring groups for dye-sensitized solar cells ACS Appl. Mater. Interfaces 2015, 7, 3427-3455.

[69] Materna, K. L.; Crabtree, R. H.; Brudvig, G. W. Anchoring groups for photocatalytic water oxidation on metal oxide surfaces Chem. Soc. Rev. 2017, 46, 6099-6110. 